\title{
Study of using light-burned dolomite ores as raw material to produce magnesium oxysulfate cement
}

Yuanji Chen

Postgraduate student, School of Civil Engineering, Qinghai University, Xining, P. R. China

\section{Chengyou Wu}

Associate professor, School of Civil Engineering, Qinghai University, Xining P. R. China (corresponding author: wuchengyou86@163.com)

\section{Hongfa Yu}

Professor, Department of Civil Engineering, Nanjing University of Aeronautics and Astronautics, Nanjing, P. R. China

Wenhai Chen

Postgraduate student, School of Civil Engineering, Qinghai University, Xining, P. R. China

\author{
Cong Chen \\ Postgraduate student, School of Civil Engineering, Qinghai University, \\ Xining, P. R. China \\ Shuhai Zheng \\ Undergraduate student, School of Civil Engineering, Qinghai University, \\ Xining, P. R. China \\ Fangyu Chen \\ Undergraduate student, School of Civil Engineering, Qinghai University, \\ Xining, P. R. China
}

Magnesium oxysulfate cement (MOS) prepared by light-burned dolomite has excellent performance in terms of light weight, high strength and low carbon dioxide emission. In this research, dolomite ores are used to produce MOS cement at different calcination temperatures and calcination times; the parameters investigated are the rate of loss on ignition, free lime ( $f-C a O)$, dihydrate gypsum $\left(\mathrm{CaSO}_{4} \times 2 \mathrm{H}_{2} \mathrm{O}\right)$ and impact of active magnesium oxide $(\alpha$-MgO) content exerted on the setting time and compressive strength of the MOS cement. X-ray diffraction analysis, scanning electron microscopy, the time of colour change for citric acid and hydration-heat release rate were adopted to assess the effects of calcination temperature, calcination time and the molar ratio of $\alpha$-magnesium oxide/magnesium sulfate on the MOS cement. The experimental results showed that the MOS cement prepared by dolomite ores at the calcination temperature of $850^{\circ} \mathrm{C}$ for $30 \mathrm{~min}$ with the $\alpha$-magnesium oxide/magnesium sulfate molar ratio of 4 demonstrates better mechanical properties than those made in other circumstances. In addition, the main strength phase of MOS cement with tri-sodium citrate dihydrate $\left(\mathrm{Na}_{3} \mathrm{C}_{6} \mathrm{H}_{5} \mathrm{O}_{7} \cdot 2 \mathrm{H}_{2} \mathrm{O}\right)$ generated by light-burned dolomite ores is the needle-like $5 \mathrm{Mg}(\mathrm{OH})_{2} \cdot \mathrm{MgSO}_{4} \cdot 7 \mathrm{H}_{2} \mathrm{O}$ crystal phase.

\section{Notation}

$M_{\mathrm{MgO}} \quad$ molecular weight of magnesium oxide

$M_{\mathrm{H}_{2} \mathrm{O}} \quad$ molecular weight of water

$m_{1}, m_{2} \quad$ mass of magnesium oxide before and after reacting with water for $3 \mathrm{~h}$ at a temperature of $105^{\circ} \mathrm{C}$, respectively

$W_{1}, W_{2}$ mass of dolomite before and after calcinating, respectively

$\omega(\mathrm{CaO})$ content of calcium oxide

$\omega(\mathrm{MgO})$ content of magnesium oxide

$\Delta \mathrm{G} \quad$ gibbs free energy

\section{Introduction}

Magnesium oxysulfate (MOS) cement is a new kind of magnesia cementitious material which is energy saving, environmentally friendly and air dried. It is also well known because it offers certain advantages, including light weight, high strength, good fire resistance, strong water resistance and steel protection following the addition of additives such as citric and phosphoric acids (Kahle, 1972; Kishimoto and Yamamoto, 2009; Wu et al., 2015, 2017). MOS cement is typically generated by mixing a certain concentration of magnesium sulfate solution with active magnesium oxide ( $\alpha-\mathrm{MgO})$ (Runčevski et al., 2013). In addition, $\alpha$-magnesium oxide is used in producing the magnesium cement that is often derived from light-burned magnesite $\left(\mathrm{MgCO}_{3}\right)$ (Haper, 2013). However, the unique features of magnesite are its uneven distribution and relatively concentrated reserves. For example, one-third of the world's magnesite reserves are concentrated in China. Owing to these geographical restrictions, the production cost of magnesium sulfate cement is higher than Portland cement, limiting its popularisation.

As a carbonate mineral of trigonal system, dolomite $(\mathrm{CaMg}$ $\left.\left(\mathrm{CO}_{3}\right)_{2}\right)$ is regarded as a significant resource for calcium and magnesium on the Earth. In addition, it is the most common kind of rock mineral among carbonate rocks, with very abundant reserves that are widely distributed around the world. Dolomite can be used as a raw material ( $\alpha$-magnesium oxide) to produce magnesium oxychloride cement (MOC) (Altiner and Yildirim, 2017a, 2017b). Furthermore, owing to the low magnesium oxide content (about 20\%) of dolomite, the carbon dioxide $\left(\mathrm{CO}_{2}\right)$ content released from the dolomite used to prepare MOS cement during the calcination process is about one-third of the amount released from calcined magnesite. Therefore, utilising dolomite instead of magnesite in the process of producing MOS cement and its products can be compatible with the concept of environmental protection; also, by using domestic resources effectively, the transportation cost can be 
notably reduced, leading to a reduced production cost of MOS cement as well. In addition, utilising light-burned dolomite to produce MOS cement represents high economic efficiency and social benefits, leading to the popularisation of MOS cement.

In recent years, several scholars have attempted to study the use of dolomite to produce magnesium cement. Altiner and Yildirim (2016, 2017a, 2017b) produced MOC cement by the reaction of magnesium oxide and magnesium chloride $\left(\mathrm{MgCl}_{2}\right)$ that were obtained from dolomite by a method of leaching-carbonation-evaporation-pyrohydrolysis. Chernykh et al. (2015) added chloride additives during the calcination process of dolomite rocks, leading to a decrease in the decomposition temperature of magnesite while controlling the thermal decomposition for calcium carbonate $\left(\mathrm{CaCO}_{3}\right)$ as well, resulting in a weakening of the negative effects of free lime (f-CaO) on cement. All of these experiences have provided a valuable theoretical foundation for the present study.

One of the important factors to affect the performance of cement is the type of hydration product. According to the results of Demediuk and Cole (1957), four kinds of magnesium subsulfate are available in the form of a $\mathrm{MgO}-\mathrm{MgSO}_{4}-\mathrm{H}_{2} \mathrm{O}$ ternary system acting in a temperature range from 30 to $120^{\circ} \mathrm{C}$. These four kinds of magnesium subsulfate are $5 \mathrm{Mg}$ $(\mathrm{OH})_{2} \cdot \mathrm{MgSO}_{4} \cdot 2$ or $3 \mathrm{H}_{2} \mathrm{O}(5 \cdot 1 \cdot 3$ phase or $5 \cdot 1 \cdot 2$ phase $), 3 \mathrm{Mg}$ $(\mathrm{OH})_{2} \cdot \mathrm{MgSO}_{4} \cdot 8 \mathrm{H}_{2} \mathrm{O} \quad(3 \cdot 1 \cdot 8$ phase $), \quad \mathrm{Mg}(\mathrm{OH})_{2} \cdot \mathrm{MgSO}_{4} \cdot 5 \mathrm{H}_{2} \mathrm{O}$ $(1 \cdot 1 \cdot 5$ phase $)$ and $\mathrm{Mg}(\mathrm{OH})_{2} \cdot 2 \mathrm{MgSO}_{4} \cdot 3 \mathrm{H}_{2} \mathrm{O}(1 \cdot 2 \cdot 3$ phase $)$. In the 1980 s, Urwong and Sorrell (1980) found that, in the phase of $\mathrm{MgO}, \quad \mathrm{Mg}(\mathrm{OH})_{2}, \quad 3 \mathrm{Mg}(\mathrm{OH})_{2} \cdot \mathrm{MgSO}_{4} \cdot 8 \mathrm{H}_{2} \mathrm{O} \quad(3 \cdot 1 \cdot 8$ phase $)$, $\mathrm{MgSO}_{4} \cdot 7 \mathrm{H}_{2} \mathrm{O}, \mathrm{MgSO}_{4} \cdot 6 \mathrm{H}_{2} \mathrm{O}, \mathrm{MgSO}_{4} \cdot \mathrm{H}_{2} \mathrm{O}$ were stable at $23^{\circ} \mathrm{C}$, and cements containing $>50 \mathrm{wt} \% 3 \cdot 1 \cdot 8$ phase could not be made from magnesium oxide and magnesium sulfate $\left(\mathrm{MgSO}_{4}\right)$ solutions at $23^{\circ} \mathrm{C}$, which was also the main reason for the low strength of this cement. Wu et al. (2015) and Runčevski et al. (2013) utilised appropriate additives such as citric, phosphoric and tartaric acids to produce a new oxysulfate $5 \mathrm{Mg}$ $(\mathrm{OH})_{2} \cdot \mathrm{MgSO}_{4} \cdot 7 \mathrm{H}_{2} \mathrm{O}(5 \cdot 1 \cdot 7$ phase $)$ in MOS cement in order to enhance the strength and water resistance of MOS cement.

It is well known around the world that the content of $\alpha$-magnesium oxide is an important factor to affect the mechanical and deformation properties of MOS cement. However, the content of $\alpha$-magnesium oxide is related to its calcination process. In this study, the authors made attempts to obtain different $\alpha$-magnesium oxide contents with different calcination processes and characteristics of dolomite, by means of the loss rate on ignition of dolomite, the content of $\alpha$-magnesium oxide, the free lime content, Brunauer-Emmett-Teller (BET) surface, the time of colour change for citric acid and so on. Then, the setting time, compressive strength and the hydration-heat release rate were investigated in MOS cements produced using dolomite under different calcination processes and molar ratios for $\alpha$-magnesium oxide/magnesium sulfate. In addition, the microstructures of the MOS cement were analysed using X-ray diffraction (XRD) and scanning electron microscopy (SEM).

\section{Materials and experimental procedures}

\section{Raw materials}

The dolomite ores used were obtained from Hebei province, China. Their main chemical compositions were determined by semi-quantitative (SQX) analysis method and analysed using X-ray fluorescence (XRF, ZSX Primus II), conducted by a standardless analysis, and the results are presented in Table 1. Figure 1 shows the XRD diffractogram of dolomite, showing that the main composition of dolomite mineral is $\mathrm{CaCO}_{3} \cdot \mathrm{MgCO}_{3}$. Analytically pure tri-sodium citrate dihydrate (as an additive, $\mathrm{Na}_{3} \mathrm{C}_{6} \mathrm{H}_{5} \mathrm{O}_{7} \cdot 2 \mathrm{H}_{2} \mathrm{O}$ (CA)) and magnesium sulfate heptahydrate $\left(\mathrm{MgSO}_{4} \cdot 7 \mathrm{H}_{2} \mathrm{O}\right)$ were purchased from Jinan Guofeng Chemical Industry Co., Ltd. The standard sand $\left(\mathrm{SiO}_{2} \geqq 98 \%\right)$ was manufactured according to ISO 679:1989 (ISO, 1989) and BS EN 196-1 (BSI, 2005), prepared by Xiamen ISO Standard Sand Co., Ltd.

\section{Preparation of active magnesium oxide}

In this paper, the thermogravimetry/differential scanning calorimetry (TG/DSC) of dolomite was conducted using simultaneous thermal analysers (TGA/DSC-TG, STA449F3/DSC200F3) at a temperature range from 30 to $1000^{\circ} \mathrm{C}$, with a heating rate of $10.0^{\circ} \mathrm{C} / \mathrm{min}$ in nitrogen conditions. Furthermore, the dolomite was calcinated using a high-temperature electric furnace, with the heating rate controlled at $15^{\circ} \mathrm{C} / \mathrm{min}$. According to Figure 2, the experimental temperatures were set from 750 to $900^{\circ} \mathrm{C}$, with intervals of $50^{\circ} \mathrm{C}$, and the calcination times were set as 0.5 to $2.5 \mathrm{~h}$ with the interval of $0.5 \mathrm{~h}$. Afterwards, the calcined dolomite ores were crushed using a jaw crusher and the crushed dolomite ores were then ground into powder by a ball mill with an angular speed of $45 \mathrm{rad} / \mathrm{min}$ for $60 \mathrm{~min}$. Finally, magnesium oxide was obtained, derived from light-burned dolomite ores, with an average particle size of $D_{90}<74 \mu \mathrm{m}$ (according to GB/T 14799-2005 (SAC, 2005): Geotextiles and geotextilerelated products - Determination of the effective opening size Dry sieving method) by passing through a $74 \mu \mathrm{m}$ sieve.

Table 1. Chemical composition of dolomite ores

\begin{tabular}{|c|c|c|c|c|c|c|c|}
\hline Composition & $\begin{array}{l}\text { Magnesium } \\
\text { oxide (MgO) }\end{array}$ & $\begin{array}{c}\text { Calcium } \\
\text { oxide }(\mathrm{CaO})\end{array}$ & $\begin{array}{c}\text { Silicon } \\
\text { dioxide }\left(\mathrm{SiO}_{2}\right)\end{array}$ & $\begin{array}{c}\text { Iron (III) } \\
\text { oxide }\left(\mathrm{Fe}_{2} \mathrm{O}_{3}\right)\end{array}$ & $\begin{array}{c}\text { Aluminium } \\
\text { oxide }\left(\mathrm{Al}_{2} \mathrm{O}_{3}\right)\end{array}$ & $\begin{array}{c}\text { Sodium } \\
\text { oxide }\left(\mathrm{Na}_{2} \mathrm{O}\right)\end{array}$ & $\begin{array}{c}\text { Carbon } \\
\text { dioxide }\left(\mathrm{CO}_{2}\right)\end{array}$ \\
\hline By mass: \% & $20 \cdot 6$ & 31 & 0.103 & 0.110 & 0.0366 & 0.0195 & $48 \cdot 1$ \\
\hline
\end{tabular}




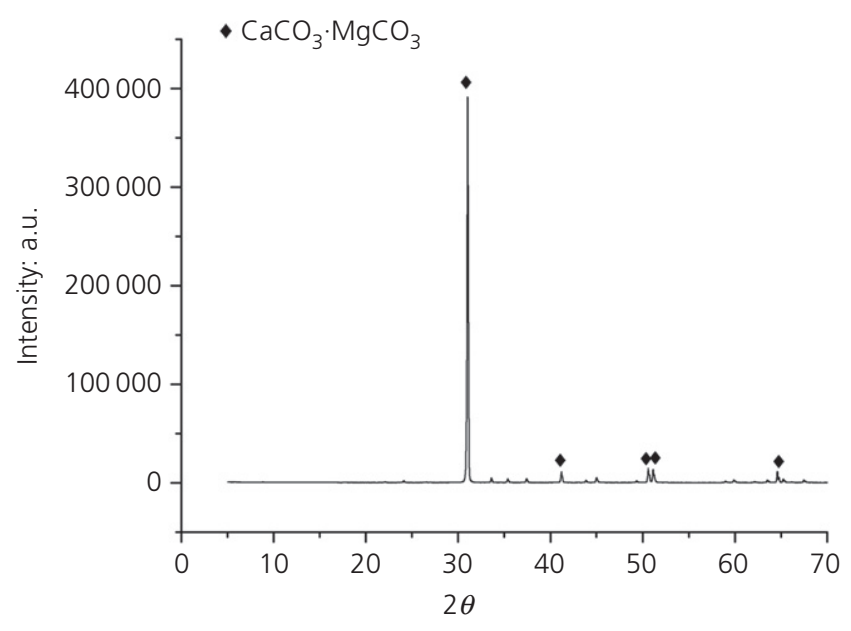

Figure 1. XRD diffractogram of dolomite ores

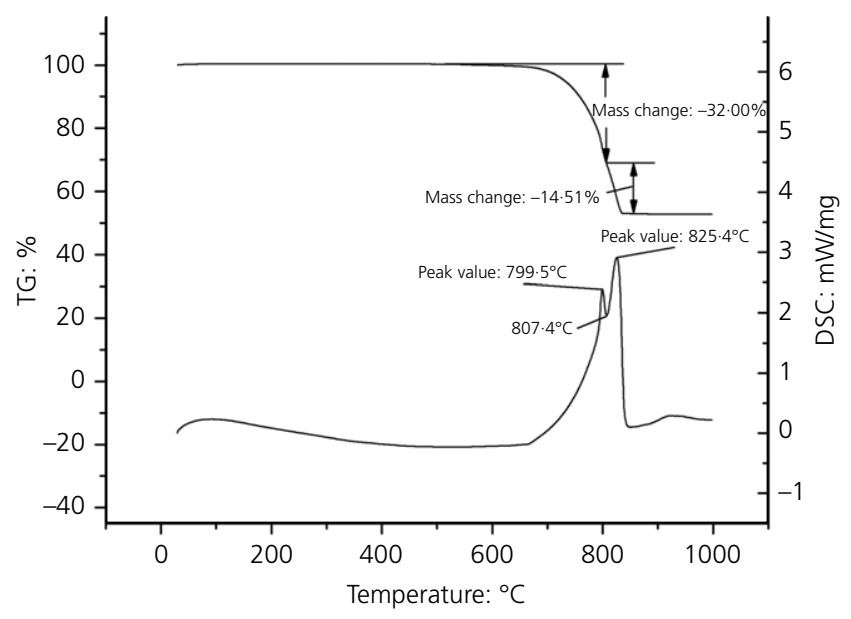

Figure 2. TG-DTA of dolomite ores

The magnesium oxide obtained from the above process contains $\alpha$-magnesium oxide and over-burned magnesium oxide, and only the $\alpha$-magnesium oxide participates in the hydration process when producing the MOS cement in the early stages (Li and Chau, 2008). The loss rate of ignition of light-burned dolomite can be determined by Equation 1 and the content of $\alpha$-magnesium oxide derived from calcined dolomite can be found by the standard hydration method using Equation 2 according to the report by Dong et al. (2010).

1. $\operatorname{LOI}(\%)=\frac{W_{1}-W_{2}}{W_{1}} \times 100 \%$

where $W_{1}$ and $W_{2}$ represent the mass of dolomite before and after calcinating, respectively.

2. $\omega(\mathrm{MgO})=\left\{\left[\frac{m_{1}-m_{2}}{m_{1}}-\omega(\mathrm{CaO})\right] \times \frac{M_{\mathrm{MgO}}}{M_{\mathrm{H}_{2} \mathrm{O}}}\right\} \times 100 \%$ where $m_{1}$ and $m_{2}$ are the mass of magnesium oxide before and after reacting with water for $3 \mathrm{~h}$ at a temperature of $105^{\circ} \mathrm{C}$, respectively. $M_{\mathrm{MgO}}$ and $M_{\mathrm{H}_{2} \mathrm{O}}$ denote the molecular weight of magnesium oxide and water, respectively. $\omega(\mathrm{CaO})$ can be titrated by using an ethylene diamine tetraacetic acid $\left(\mathrm{C}_{10} \mathrm{H}_{16} \mathrm{~N}_{2} \mathrm{O}_{8}\right.$, EDTA) standard solution according to Dong et al. (2011).

\section{Sample preparation}

According to Table 1, the content of magnesium oxide in dolomite is relatively low. In view of this, the molar ratios of $\alpha$-magnesium oxide/magnesium sulfate of MOS cement were set to 3, 4 and 5. First, $\mathrm{MgSO}_{4} \cdot 7 \mathrm{H}_{2} \mathrm{O}$ was dissolved in deionised water to form a $25.0 \%$ magnesium sulfate solution (the molar ratio of water/magnesium sulfate was 20) (Wu et al., 2017).

Then a certain amount of magnesium oxide at different calcination conditions was mixed equally with $0 \cdot 5 \%$ analytically pure trisodium citrate dihydrate $\left(\mathrm{Na}_{3} \mathrm{C}_{6} \mathrm{H}_{5} \mathrm{O}_{7} \cdot 2 \mathrm{H}_{2} \mathrm{O}\right.$, by the weight of the magnesium oxide), added to the prepared magnesium sulfate solution and then stirred evenly to form the MOS cement paste. Finally, the MOS cement paste was placed into steel moulds with dimensions of $20 \mathrm{~mm} \times$ $20 \mathrm{~mm} \times 20 \mathrm{~mm}$ under conditions of sustained temperature of $20 \pm 3^{\circ} \mathrm{C}$ and relative humidity of $(50 \pm 5) \%$ for about $24 \mathrm{~h}$ before demoulding.

\section{Analysing the sample}

The hydration rate of magnesium oxide, derived from lightburned dolomite under different calcination processes, was determined by the colour-changing method using citric acid (Ren et al., 2010). The free lime in light-burned dolomite could be titrated using an EDTA standard solution according to Dong et al. (2011). The specific surface area of the samples was determined by BET method with a specific surface area instrument (Gemini VII 2390). The crystal phase composition of light-burned dolomite was examined by XRD (PANalytical X'PROPert) and the relative amount of different crystal phases was analysed using Topas $4 \cdot 2$, and assessed by the Rietveld method (Rietveld, 1967). Moreover, the grain size of the specimen was computed using Scherrer's equation in terms of the half peak width of the crystal face for magnesium oxide content.

The initial and final setting times for the MOS cement were tested by way of a Vicat apparatus according to GB/T 1346-2011 (SAC, 2011): Standard test method for water requirement of normal consistency, setting time and soundness of Portland cement. The compressive strength of the MOS cement, which had been derived from light-burned dolomite by air curing for $1,3,7$ and $28 \mathrm{~d}$, was examined by a testing machine with the maximum load of $300 \mathrm{kN}$ and a loading rate of $0.3 \mathrm{kN} / \mathrm{s}$ according to cement strength test standard methodology (GB 175-2007 (SAC, 2007)). 
The hydration-heat release rates of the MOS mortars (the molar ratio of $\alpha$-magnesium oxide/magnesium sulfate and the weight ratio of standard sand to magnesium oxide were set to 4 and 2, respectively) derived from lightburned dolomite after doing several calcination processes were determined by way of a tester for cement hydration heat (YT12659-16) according to the GB/T 12959-2008 standard (SAC, 2008).

Additionally, the crystal-phase compositions of the MOS cement were examined by X-ray diffractometer with $\mathrm{CuK} \alpha$ radiation $(\lambda=0 \cdot 15419 \mathrm{~nm})$ over a $2 \theta$ range from $5^{\circ}$ to $70^{\circ}$, and the relative amounts of the different crystal phases were analysed using Topas 4.2. The microstructure and energydispersive X-ray spectroscopy (EDS) results for the MOS cement cured in air for $28 \mathrm{~d}$ were tested by a SEM (JSM$5610 \mathrm{LV}$ ) on fractured surfaces after gold plating.

\section{Results and discussion}

Effects of different calcination processes on the properties of magnesium oxide obtained from dolomite Figure 2 shows the TG analysis results of dolomite ores from 30 to $1000^{\circ} \mathrm{C}$. According to Figure 2, it can be seen that two distinct endothermic peaks appear at $799 \cdot 5^{\circ} \mathrm{C}$ and $825 \cdot 4^{\circ} \mathrm{C}$ on the DSC curve. The first endothermic peak appears as magnesite decomposed into magnesium oxide at $799 \cdot 5^{\circ} \mathrm{C}$, whereas the second one arises when calcium carbonate decomposed into calcium oxide at $825.4^{\circ} \mathrm{C}$, as has been indicated in a previous study (Chernykh et al., 2015). Therefore, the temperature range in the experimental testing varies from 750 to $900^{\circ} \mathrm{C}$ with an interval of $50^{\circ} \mathrm{C}$.
The XRD analysis of dolomite ores with different calcination processes, as shown in Figure 3, reveals that the diffraction peaks of $\mathrm{CaCO}_{3} \cdot \mathrm{MgCO}_{3}$ gradually disappeared by increasing the calcination temperature and calcination time. Moreover, the diffraction peaks of calcium carbonate and magnesium oxide simultaneously appeared. In addition, the diffraction peak of calcium hydroxide $\left(\mathrm{Ca}(\mathrm{OH})_{2}\right)$ appeared after calcination for $1.5 \mathrm{~h}$ at the temperature of $850^{\circ} \mathrm{C}$. In contrast with the results presented, the diffraction peak of calcium carbonate decreased, demonstrating that relatively more calcium carbonate decomposed into calcium oxide, as well as reacting with water in the air. According to the results presented in Table 2, it was confirmed that the content of $\mathrm{CaCO}_{3} \cdot \mathrm{MgCO}_{3}$ declined while the content of $\alpha$-magnesium oxide rose gradually by increasing the calcination temperature and calcination time, which is consistent with previous studies (Zhao, 2010).

Table 3 shows the characteristics of magnesium oxide obtained from dolomite using different calcination processes. The loss on ignition of dolomite grew by enhancing the calcination temperature and time, whereas the content of $\alpha$-magnesium oxide showed an increase at first and decreased later. When the calcination temperature was low or the calcination time was short, magnesite could not be fully decomposed. With an increase of the calcination temperature, the content of $\alpha$-magnesium oxide increased through decomposition of magnesite. When the decomposition process of magnesite was completed, the crystal size of magnesium oxide increased as well (see Table 3). This is due to the growth of the magnesium oxide crystal as the calcination temperature increased, confirming a research study conducted by Tan et al. (2014). This indicates that deflections of crystal particles reduced and the

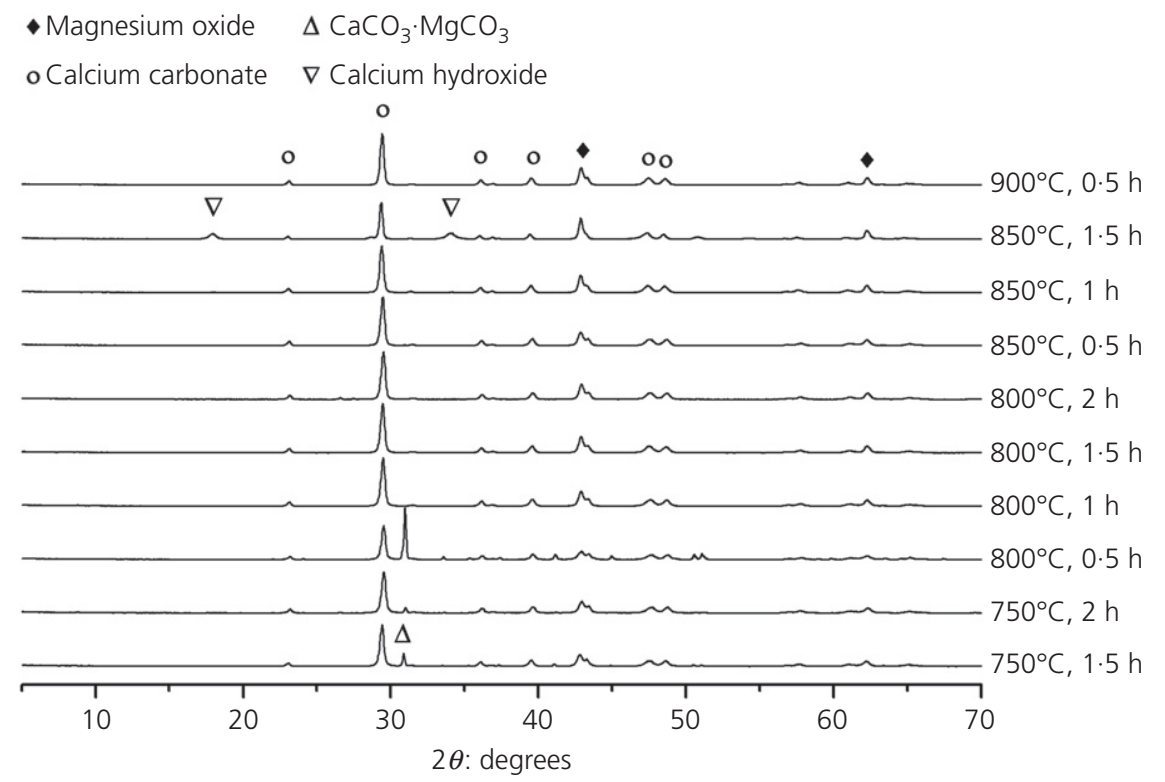

Figure 3. XRD diffractogram of dolomite with different calcination processes 
Table 2. Phase composition of dolomite with different calcination processes (by mass \%)

\begin{tabular}{|c|c|c|c|c|c|}
\hline $\begin{array}{l}\text { Temperature: } \\
{ }^{\circ} \mathrm{C}\end{array}$ & $\begin{array}{l}\text { Calcination } \\
\text { times: } \mathbf{h}\end{array}$ & $\begin{array}{l}\text { Calcium-magnesium carbonate } \\
\left(\mathrm{CaCO}_{3} \cdot \mathrm{MgCO}_{3}\right)\end{array}$ & Calcium carbonate $\left(\mathrm{CaCO}_{3}\right)$ & $\begin{array}{l}\text { Magnesium } \\
\text { oxide (MgO) }\end{array}$ & $\begin{array}{l}\text { Calcium hydroxide } \\
\left(\mathrm{Ca}(\mathrm{OH})_{2}\right)\end{array}$ \\
\hline 750 & $1 \cdot 5$ & $24 \cdot 35$ & $54 \cdot 23$ & $19 \cdot 96$ & 1.46 \\
\hline 750 & 2 & $6 \cdot 39$ & $67 \cdot 28$ & 24.67 & 1.66 \\
\hline 800 & 0.5 & $40 \cdot 88$ & $42 \cdot 56$ & $15 \cdot 65$ & 0.91 \\
\hline 800 & 1 & 1.98 & $71 \cdot 83$ & 24.92 & $1 \cdot 27$ \\
\hline 800 & $1 \cdot 5$ & 1.02 & $72 \cdot 05$ & $25 \cdot 34$ & $1 \cdot 59$ \\
\hline 800 & 2 & 0.63 & $69 \cdot 85$ & $25 \cdot 26$ & $4 \cdot 26$ \\
\hline 850 & 0.5 & 0.63 & $72 \cdot 66$ & $25 \cdot 35$ & $1 \cdot 36$ \\
\hline 850 & 1 & 0.32 & $68 \cdot 75$ & $26 \cdot 23$ & $4 \cdot 7$ \\
\hline 850 & $1 \cdot 5$ & 0.38 & $52 \cdot 64$ & $30 \cdot 87$ & $16 \cdot 11$ \\
\hline 900 & 0.5 & 0.35 & $65 \cdot 51$ & $26 \cdot 58$ & $7 \cdot 56$ \\
\hline
\end{tabular}

Table 3. Properties of magnesium oxide from dolomite after different calcination processes

\begin{tabular}{|c|c|c|c|c|c|c|}
\hline $\begin{array}{l}\text { Temperature: } \\
{ }^{\circ} \mathrm{C}\end{array}$ & $\begin{array}{l}\text { Calcination } \\
\text { times: } \mathbf{h}\end{array}$ & $\begin{array}{l}\text { Loss on } \\
\text { ignition: \% }\end{array}$ & $\begin{array}{l}\text { Active magnesia } \\
\text { content: } \%\end{array}$ & $\begin{array}{c}\text { Crystallite } \\
\text { dimensions: } \mathrm{nm}\end{array}$ & $\begin{array}{l}\text { Citric acid colour } \\
\text { change time: } \min \end{array}$ & $\begin{array}{l}\text { BET surface: } \\
\mathrm{m}^{2} / \mathrm{g}\end{array}$ \\
\hline 700 & 2 & 5.06 & 3.95 & - & - & - \\
\hline 750 & 1 & $4 \cdot 7$ & $3 \cdot 82$ & - & - & - \\
\hline 750 & 1.5 & $19 \cdot 42$ & $17 \cdot 68$ & 24.95 & $6 \cdot 98$ & $10 \cdot 8512$ \\
\hline 750 & 2 & $21 \cdot 82$ & $19 \cdot 3$ & 49.91 & 6.75 & 8.9884 \\
\hline 800 & $0 \cdot 5$ & $17 \cdot 28$ & $15 \cdot 66$ & $22 \cdot 18$ & 22.93 & $10 \cdot 1095$ \\
\hline 800 & 1 & $21 \cdot 21$ & 18.44 & $33 \cdot 28$ & $5 \cdot 43$ & $8 \cdot 6493$ \\
\hline 800 & 1.5 & $22 \cdot 64$ & $18 \cdot 75$ & $57 \cdot 02$ & $3 \cdot 25$ & 6.6399 \\
\hline 800 & 2 & 22.93 & $18 \cdot 43$ & 64.88 & $3 \cdot 75$ & $7 \cdot 7956$ \\
\hline 850 & 0.5 & $21 \cdot 24$ & $17 \cdot 66$ & 24.95 & $6 \cdot 17$ & 8.6737 \\
\hline 850 & 1 & $22 \cdot 84$ & $18 \cdot 22$ & $40 \cdot 92$ & $3 \cdot 42$ & $5 \cdot 2024$ \\
\hline 850 & 1.5 & $25 \cdot 07$ & 18.01 & $79 \cdot 84$ & 0 & $7 \cdot 791$ \\
\hline 850 & 2 & $30 \cdot 41$ & $17 \cdot 76$ & - & 0 & $9 \cdot 3837$ \\
\hline 900 & 0.5 & $25 \cdot 67$ & $16 \cdot 11$ & $36 \cdot 29$ & 0 & 5.9003 \\
\hline
\end{tabular}

magnesium oxide content with appropriate degree of crystallisation has less activity for reacting with $\mathrm{OH}^{-}, \mathrm{SO}_{4}{ }^{2+}$ and water in magnesium sulfate solution. Figure 4 depicts the relationship of the time of colour change for citric acid and the $\alpha$-magnesium oxide content with increase in calcination time at the temperature of $800^{\circ} \mathrm{C}$. The figure shows that, with the changing colour of citric acid, during the process, there is a tendency initially to drop down and then climb up, whereas in the $\alpha$-magnesium oxide content, an opposite trend is dominant, first climbing up and then falling back down. Using Table 3, a conclusion can be drawn that the rate of reaction of the magnesium oxide with water would initially increase and eventually decrease with increasing calcination temperature and time.

It can be seen clearly from Table 3 that the crystal size of magnesium oxide gradually expanded, which led to the reduction of the BET surface as calcination temperature rose. For instance, when the calcination time was $0.5 \mathrm{~h}$ and the calcination temperature varied from 800 to $900^{\circ} \mathrm{C}$, the crystal size of the magnesium oxide content gradually enlarged from $22.18 \mathrm{~nm}$ to $36.29 \mathrm{~nm}$, while the trend for the values of BET surface experienced a decline from $10 \cdot 1095 \mathrm{~m}^{2} / \mathrm{g}$ to $5.9003 \mathrm{~m}^{2} / \mathrm{g}$. However, the BET surface of the samples had a

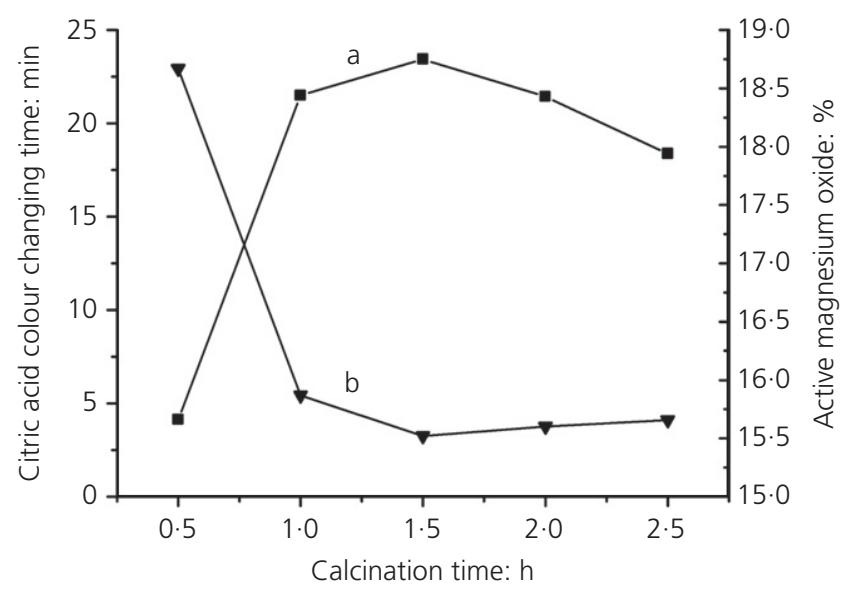

Figure 4. The relationship of citric acid colour changing time and $\alpha$-magnesium oxide content at the calcination temperature of $800^{\circ} \mathrm{C}$ (a: $\alpha$-magnesium oxide content; b: citric acid colour changing time)

different tendency, which at the beginning showed a reduction and finally increased when the calcination time grew (see Table 3). The BET surface area decreased in step with 
increasing the calcination time from 0.5 to $1.5 \mathrm{~h}$ at $800^{\circ} \mathrm{C}$. However, comparing Table 2 with Table 3, the BET surface area increased following the decomposition of calcium carbonate as the calcination time extended from 1.5 to $2 \mathrm{~h}$ at the calcination temperature of $800^{\circ} \mathrm{C}$. On the one hand, the structure of calcium carbonate weakened as little calcium carbonate had been decomposed into calcium oxide. On the other hand, the calcium oxide had generated a low degree of crystallisation and relatively more crystal particle defects, which led to enhancing the BET surface area.

As shown in Figure 2, the temperature of decomposition of magnesite was within $700^{\circ} \mathrm{C}$. However, the decomposition process was slow at the mentioned temperature, where the loss of ignition was only $5 \cdot 06 \%$ after passing $2 \mathrm{~h}$ (see Table 3), and the content of $\alpha$-magnesium oxide was around $3.95 \%$, which resulted in a low water-cement ratio $(w / c)$. Similarly, the loss of ignition was about $4 \cdot 7 \%$ at $750^{\circ} \mathrm{C}$ after $1 \mathrm{~h}$ passing for the calcination process and this may not fully satisfy the requirements for forming the cement paste. In addition, free lime has shown a harmful effect on the stability, physical properties and hardening of cement when exceeding a certain content (Shi, 1995). For example, with the loss of ignition within $25.07 \%$ at the temperature of $850^{\circ} \mathrm{C}$ after passing $1.5 \mathrm{~h}$, MOS cement could not be formed because the reaction was too intense and hardening took place very rapidly. Therefore, MOS cement cannot be made with either higher or lower loss of ignition.

Accordingly, the physical properties of magnesium oxide content, derived from light-burned dolomite with different calcination processes, would inevitably affect the solidification, hardening, hydration process and other physical properties of MOS cement, which will be further discussed in the following sections.

\section{Investigating the effects of different calcination} processes and $\alpha$-magnesium oxide/magnesium sulfate on setting time of MOS cement

Setting time is regarded as one of the main properties of cement which can reflect its hardening rate. Table 4 represents the setting time of MOS cement. As presented in Table 4, the setting time increased gradually after the temperature or time increased. For instance, the initial setting time of MOS cement with $\alpha$-magnesium oxide/magnesium sulfate ratio equal to 4 was $1 \cdot 76,3 \cdot 51,4.67$ and $5 \cdot 78 \mathrm{~h}$, respectively, when the calcination time ranged through $0 \cdot 5,1 \cdot 0,1 \cdot 5$ to $2 \mathrm{~h}$ at the calcination temperature of $800^{\circ} \mathrm{C}$. According to the previous section 'Effects of different calcination processes on the properties of magnesium oxide obtained from dolomite', with higher calcination temperature and longer calcination time, the crystal size of magnesium oxide content expands and the degree of crystallisation improves. This is due to there being fewer active sites for reacting with $\mathrm{OH}^{-}, \mathrm{SO}_{4}{ }^{2+}$ and water in magnesium sulfate solution, which decelerated the hydration reaction and duration of the setting time of MOS cement. Moreover, higher molar ratios ( $\alpha$-magnesium oxide/magnesium sulfate) of MOS cement indicated a lower setting time. For instance, the initial setting time of MOS cement was $4.72 \mathrm{~h}$ when the calcination time was $0.5 \mathrm{~h}$ at the temperature of $850^{\circ} \mathrm{C}$ with $\alpha$-magnesium oxide/magnesium sulfate ratio equal to 3 , whereas the initial setting time was $1.78 \mathrm{~h}$ when the $\alpha$-magnesium oxide/ magnesium sulfate ratio was equal to 5 for the same calcination conditions. When the water/magnesium sulfate ratio in the magnesium sulfate solution remained unchanged, the relative content of cementitious materials available in the cement increased because the value of $\alpha$-magnesium oxide/magnesium sulfate was enhanced, and the content of magnesium oxide that participated in the hydration process per unit mass of cement slurry increased as well. In this way, the enhanced rate of hydration products led to diminishing the setting time of MOS cement. Unfortunately, in this study, the setting time of all the samples containing MOS cement was long.

The hydration of magnesium oxide with magnesium sulfate solution, produced by dolomite after conducting several calcination processes, would explicitly affect the hydration heat release rate of MOS cement. As shown in Figure 5, the hydration rate of MOS cement produced by light-burned dolomite was similar to MOS cement generated by magnesite and Portland cement (Jeffery, 2007; Wu et al., 2017), which could also be classified into five periods: pre-induction, induction, acceleration, deceleration and a stable period. According to Figure 5, the hydration process of MOS cement produced by dolomite is similar to MOS cement with light-burned magnesite (LBM) as raw material based on the report by Wu et al. (2017). In contrast, the hydration-heat release rate of MOS cement produced by light-burned dolomite ores was roughly three times lower than the MOS cement produced by LBM. In addition, another conclusion can be reached from Figure 5: higher calcination temperature and longer calcination time could extend the duration of induction and acceleration periods of MOS cement produced by light-burned dolomite. This once more verifies that the setting time of MOS cement

Table 4. Setting time of MOS cement with different calcination processes

\begin{tabular}{|c|c|c|c|c|c|c|c|c|c|c|}
\hline Temperature: ${ }^{\circ} \mathrm{C}$ & 750 & 750 & 800 & 800 & 800 & 800 & 850 & 850 & 850 & 850 \\
\hline Calcination times: $h$ & $1 \cdot 5$ & 2 & 0.5 & 1 & $1 \cdot 5$ & 2 & 0.5 & 0.5 & 0.5 & 1 \\
\hline$\alpha$-magnesium oxide/magnesium sulfate & 4 & 4 & 4 & 4 & 4 & 4 & 3 & 4 & 5 & 4 \\
\hline Initial setting time: $\mathrm{h}$ & $1 \cdot 38$ & $2 \cdot 43$ & $1 \cdot 76$ & $3 \cdot 51$ & $4 \cdot 67$ & $5 \cdot 78$ & $4 \cdot 72$ & $3 \cdot 07$ & $1 \cdot 78$ & $5 \cdot 51$ \\
\hline Final setting time: $h$ & $10 \cdot 83$ & $11 \cdot 64$ & $10 \cdot 27$ & $12 \cdot 9$ & $15 \cdot 31$ & $16 \cdot 2$ & $15 \cdot 85$ & $13 \cdot 12$ & $11 \cdot 67$ & $16 \cdot 32$ \\
\hline
\end{tabular}




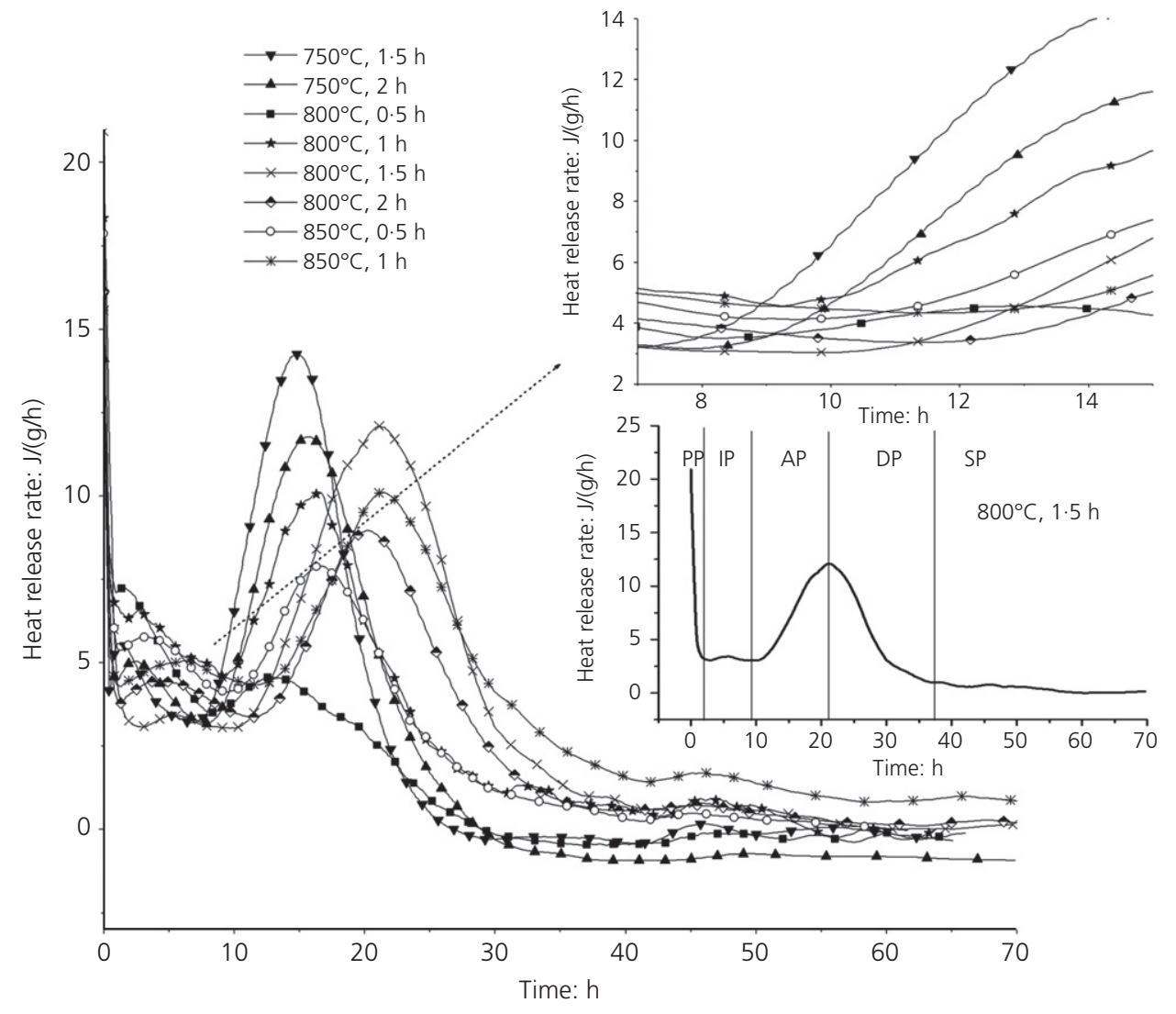

Figure 5. Heat-release rate of MOS cement with $\alpha$-magnesium oxide/magnesium sulfate ratio of 4 prepared by dolomite ores with different calcination processes (PP, pre-induction period; IP, induction period; AP, acceleration period; DP, deceleration period; SP, stable period)

Table 5. F-CaO content of light-burned dolomite with different calcination processes

\begin{tabular}{|llllllllllll}
\hline Temperature: ${ }^{\circ} \mathbf{C}$ & $\mathbf{7 5 0}$ & $\mathbf{7 5 0}$ & $\mathbf{8 0 0}$ & $\mathbf{8 0 0}$ & $\mathbf{8 0 0}$ & $\mathbf{8 0 0}$ & $\mathbf{8 5 0}$ & $\mathbf{8 5 0}$ & $\mathbf{8 5 0}$ & $\mathbf{8 5 0}$ & $\mathbf{9 0 0}$ \\
\hline Calcination times: $\mathrm{h}$ & 1.5 & 2 & 0.5 & 1 & 1.5 & 2 & 0.5 & 1 & 1.5 & 2 & 0.5 \\
F-CaO content: \% & 0.46 & 0.51 & 0.32 & 0.62 & 0.57 & 0.68 & 0.25 & 0.54 & 1.56 & 2.71 & 1.05 \\
\hline
\end{tabular}

produced by light-burned dolomite is shortened as the calcination temperature and calcination time decrease.

The results of experiments show that the MOS cement is formed very rapidly because the hydration happens quickly when the content of free lime exceeds a certain value. Based on Table 3, the times for colour changing of citric acid at the temperatures of $850^{\circ} \mathrm{C}$ for $1.5 \mathrm{~h}, 850^{\circ} \mathrm{C}$ for $2 \mathrm{~h}$ and $900^{\circ} \mathrm{C}$ for $0.5 \mathrm{~h}$ were equal to zero minutes, which indicated that free lime, derived from the light-burned dolomite, quickly reacted with water and produced calcium hydroxide that made a phenolphthalein indicator turn red. The free lime content of light-burned dolomite with different calcination processes is presented in Table 5. In fact, the samples of light-burned dolomite formed at the calcination conditions of $850^{\circ} \mathrm{C}$ for $1.5 \mathrm{~h}$, $850^{\circ} \mathrm{C}$ for $2 \mathrm{~h}$ and $900^{\circ} \mathrm{C}$ for $0.5 \mathrm{~h}$ could not make MOS cement, because of the quick reaction of magnesium oxide and magnesium sulfate solution, which made hardening occur over a short period. Figure 6 shows the MOS cement cured in $3 \mathrm{~d}$, derived from light-burned dolomite, at the calcination temperature of $850^{\circ} \mathrm{C}$ for $1.5 \mathrm{~h}$. As shown in Figure 6, a large amount of magnesium hydroxide $\left(\mathrm{Mg}(\mathrm{OH})_{2}\right)$, dihydrate gypsum $\left(\mathrm{CaSO}_{4} \cdot 2 \mathrm{H}_{2} \mathrm{O}\right)$ and calcium hydroxide have been generated; however, more magnesium oxide remained, indicating that the hydration process of MOS cement strongly correlates with Equations I and II. Therefore, when the free lime content of the light-burned dolomite exceeds $1 \%$, the production of MOS cement is often undertaken by reactions of Equations I and II. This justifies why the MOS cement cannot be formed.

I. $\mathrm{CaO}+\mathrm{H}_{2} \mathrm{O} \rightarrow \mathrm{Ca}(\mathrm{OH})_{2}$

II. $\mathrm{Ca}(\mathrm{OH})_{2}+\mathrm{MgSO}_{4}+2 \mathrm{H}_{2} \mathrm{O} \rightarrow \mathrm{CaSO}_{4} \cdot 2 \mathrm{H}_{2} \mathrm{O}+\mathrm{Mg}(\mathrm{OH})_{2}$ 


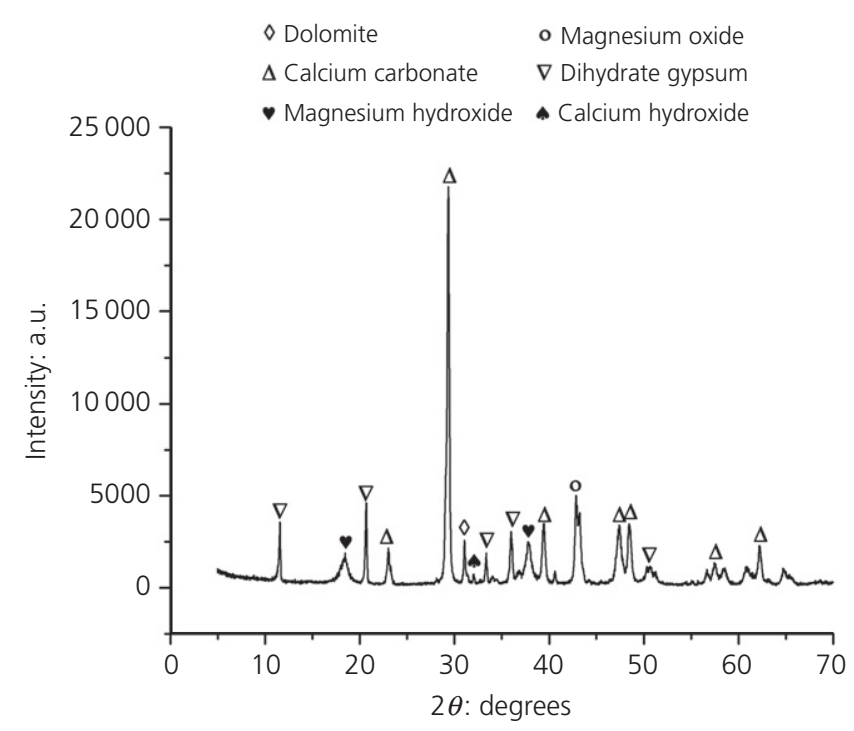

Figure 6. XRD diffractogram of MOS cement cured for $3 \mathrm{~d}$ prepared by light-burned dolomite at the calcination temperature of $850^{\circ} \mathrm{C}$ for $1.5 \mathrm{~h}$

\section{Mechanical strength of MOS cement}

Effects of different calcination processes on mechanical strength of MOS cement produced by light-burned dolomite

Figure 7 shows the compressive strength of MOS cement after curing for different times with a ratio of $\alpha$-magnesium oxide/magnesium sulfate equal to 4 under different calcination processes. It can be clearly seen that the early compressive strength of MOS cement has been gradually reduced as the calcination time increased with the curing time of $1 \mathrm{~d}$. For example, for $\mathrm{T} 800 \mathrm{~T} 0.5$ (where the first $\mathrm{T}$ denotes calcination temperature and the second $\mathrm{T}$ represents calcination time), the MOS cement derived from light-burned dolomite at a calcination temperature of $800^{\circ} \mathrm{C}$ with calcination time of $0.5 \mathrm{~h}$, which was cured in $1 \mathrm{~d}$, the compressive strength was $13.5 \mathrm{MPa}$, but the compressive strength of T800T2, which also cured in $1 \mathrm{~d}$, was equal to $0.6 \mathrm{MPa}$. According to the earlier section 'Effects of different calcination processes on the properties of magnesium oxide obtained from dolomite', the crystal size of magnesium oxide was increased as the calcination time grew, and the magnesium oxide had fewer active sites for reacting with $\mathrm{OH}^{-}$, $\mathrm{SO}_{4}{ }^{2-}$ and water in magnesium sulfate solution. In addition, it can also be observed from Figure 5 that a longer calcination time could extend the duration of the induction period and acceleration period, which makes the early compressive strength of MOS cement reduce gradually as the calcination time increases. Unfortunately, as shown in Figure 7, the compressive strength values of MOS cement (produced at $800^{\circ} \mathrm{C}$ for 1.5 and $2 \mathrm{~h}, 850^{\circ} \mathrm{C}$ for $1 \mathrm{~h}$ ) decreased at the seventh day of curing compared with the third day of curing. According to previous studies (Huang et al., 2016), MOS cement may manifest the phenomenon of strength shrinkage because of magnesium hydroxide $\left(\mathrm{Mg}(\mathrm{OH})_{2}\right)$ generation, which causes microcracking in MOS cement. Based on Table 6, the MOS cement (produced at $800^{\circ} \mathrm{C}$ for 1.5 and $2 \mathrm{~h}$, and at $850^{\circ} \mathrm{C}$ for $1 \mathrm{~h}$ ) had higher values of dihydrate gypsum, which led to the appearance of microcracks in the MOS cement due to a crystallisation swelling property along with a shrinkage phenomenon.

However, the $\alpha$-magnesium oxide content that participated in the formation of the hydration products was a key factor in determining the mechanical strength of the MOS cement. Figure 8 shows that, based on the results of the XRD diffractogram, the MOS cement with $\alpha$-magnesium oxide/magnesium sulfate ratio equal to 4 , produced by dolomite, was cured in $28 \mathrm{~d}$, and as shown later in Figure 10, according to the SEM images and EDS results, the MOS cement had been cured in $28 \mathrm{~d}$. Consequently, the hydration product in the MOS cement with CA produced by light-burned dolomite ores was a needlelike $5 \cdot 1 \cdot 7$ crystal phase, which indicated the mechanical strength of the MOS cement, as shown in Figure 8(a). This is the same for the hydration product of the $5 \cdot 1 \cdot 7$ crystal phase in the MOS cement with CA produced by light-burned magnesite, as shown

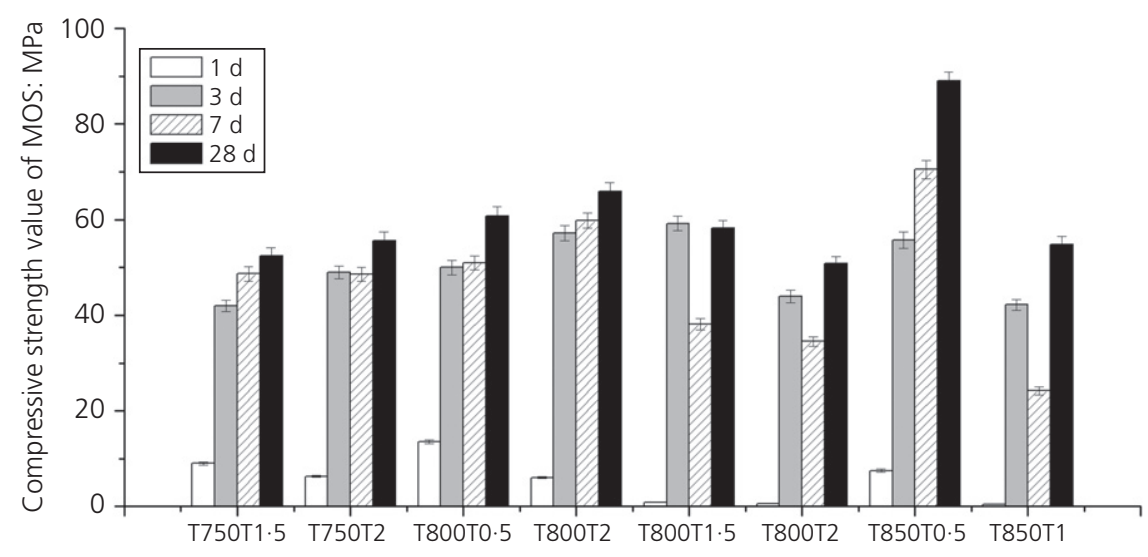

Figure 7. Compressive strength of MOS cement with $\alpha$-magnesium oxide/magnesium sulfate ratio of 4 after different curing times 
Table 6. Phase composition of MOS cement cured for $28 \mathrm{~d}$ with different calcination processes (by mass \%)

\begin{tabular}{|c|c|c|c|c|c|}
\hline $\begin{array}{l}\text { MOS } \\
\text { cement }\end{array}$ & $\begin{array}{l}\text { Calcium-magnesium carbonate } \\
\left(\mathrm{CaCO}_{3} \cdot \mathrm{MgCO}_{3}\right)\end{array}$ & $\begin{array}{l}\text { Calcium carbonate } \\
\left(\mathrm{CaCO}_{3}\right)\end{array}$ & $\begin{array}{l}\text { Magnesium oxide } \\
\text { (MgO) }\end{array}$ & $5 \cdot 1 \cdot 7$ & $\begin{array}{l}\text { Dihydrate gypsum } \\
\left(\mathrm{CaSO}_{4} \cdot 2 \mathrm{H}_{2} \mathrm{O}\right)\end{array}$ \\
\hline Т750Т0.5 & $36 \cdot 17$ & $41 \cdot 17$ & $3 \cdot 21$ & 18.04 & 1.41 \\
\hline Т750T2 & 3.41 & 57.92 & $5 \cdot 87$ & 28.08 & $4 \cdot 72$ \\
\hline Т800T0.5 & $39 \cdot 56$ & 39.63 & 2.81 & 16.95 & 1.05 \\
\hline Т800T1 & 0.36 & $65 \cdot 56$ & 8.43 & $23 \cdot 31$ & $2 \cdot 34$ \\
\hline Т800T1.5 & 0.07 & 59.96 & $6 \cdot 52$ & $29 \cdot 57$ & 3.88 \\
\hline Т800T2 & $0 \cdot 16$ & $57 \cdot 82$ & $8 \cdot 12$ & 28.01 & $5 \cdot 89$ \\
\hline Т850T0.5 & $1 \cdot 71$ & $54 \cdot 14$ & $3 \cdot 51$ & $39 \cdot 17$ & $1 \cdot 47$ \\
\hline Т850T1 & $1 \cdot 39$ & $59 \cdot 17$ & $10 \cdot 43$ & 23.96 & 5.05 \\
\hline
\end{tabular}

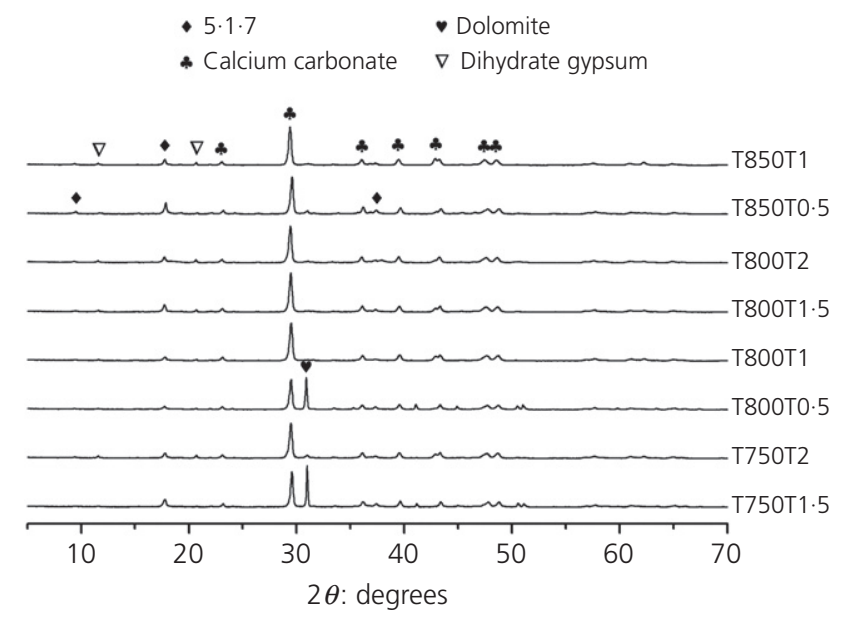

(a)

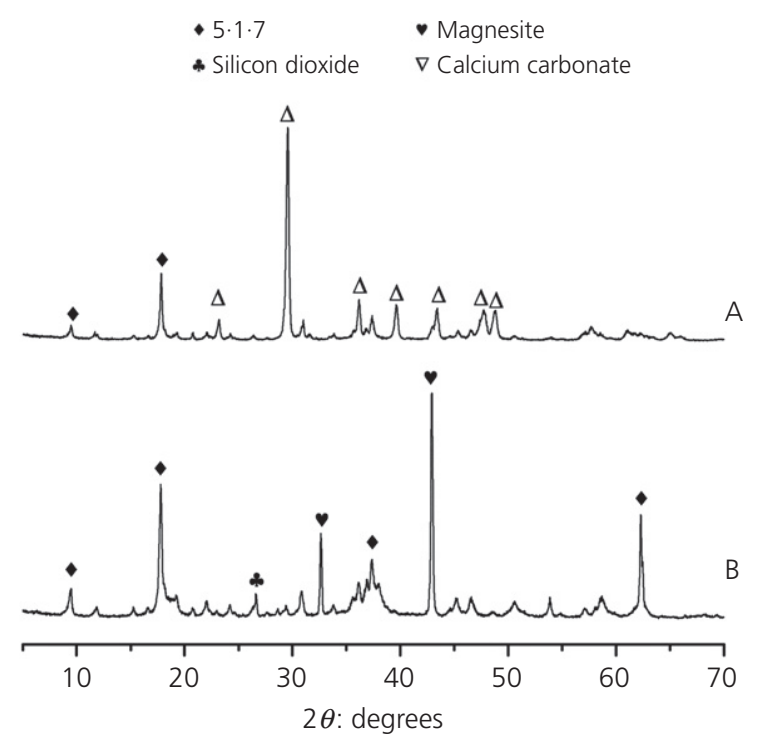

(b)

Figure 8. (a) XRD diffractogram of MOS cement with $\alpha$-magnesium oxide/magnesium sulfate ratio of 4 prepared by dolomite with different calcination processes after curing for $28 \mathrm{~d}$. (b) XRD diffractogram of MOS cement with CA after curing for $28 \mathrm{~d}$ prepared by light-burned magnesite (labelled ' $\mathrm{A}$ ') and prepared by light-burned dolomite at $850^{\circ} \mathrm{C}$ for $0.5 \mathrm{~h}$ (labelled 'B')

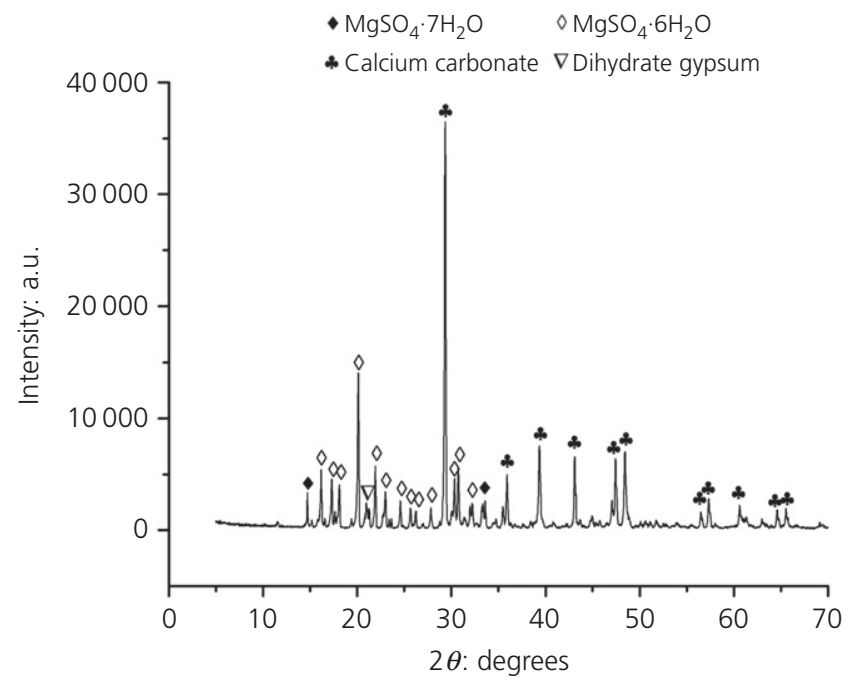

Figure 9. XRD spectra phase compositions of analytically pure calcium carbonate dissolving in magnesium sulfate solution

in Figure 8(b) (Wu et al., 2014). Accordingly, the later-age compressive strength had a trend to increase at first and then reduce later as the temperature and calcination time increased. Additionally, the $\alpha$-magnesium oxide content presented a similar trend of increasing first and then decreasing. This indicated that the later-age compressive strength of the MOS cement was related to the content of $\alpha$-magnesium oxide. For instance, when the calcination temperature of magnesium oxide was $800^{\circ} \mathrm{C}$, the compressive strengths of the MOS cement cured in $28 \mathrm{~d}$, with different calcination times of $30 \mathrm{~min}, 1 \mathrm{~h}, 1.5 \mathrm{~h}$ and $2 \mathrm{~h}$, were $60.8 \mathrm{MPa}, 65.9 \mathrm{MPa}, 68.2 \mathrm{MPa}$, and $50.8 \mathrm{MPa}$, respectively, and the content of $\alpha$-magnesium oxide under these circumstances was $15 \cdot 66 \%, 18 \cdot 44 \%, 18 \cdot 75 \%$ and $18.43 \%$ respectively. The values of the $5 \cdot 1 \cdot 7$ phase of T800T0.5, T800T1, T800T1.5 and T800T2 cured in $28 \mathrm{~d}$ showed a trend of enhancement at first and then dropping down, which is identical with the compressive strength of the MOS cement cured in $28 \mathrm{~d}$.

However, the compressive strength of the MOS cement for T850T0.5 was $89 \mathrm{MPa}$, which was much higher than T850T1, which had a compressive strength of $54.8 \mathrm{MPa}$. In addition, at 
Study of using light-burned dolomite ores as raw material to produce magnesium

oxysulfate cement

Chen, Wu, Yu et al.

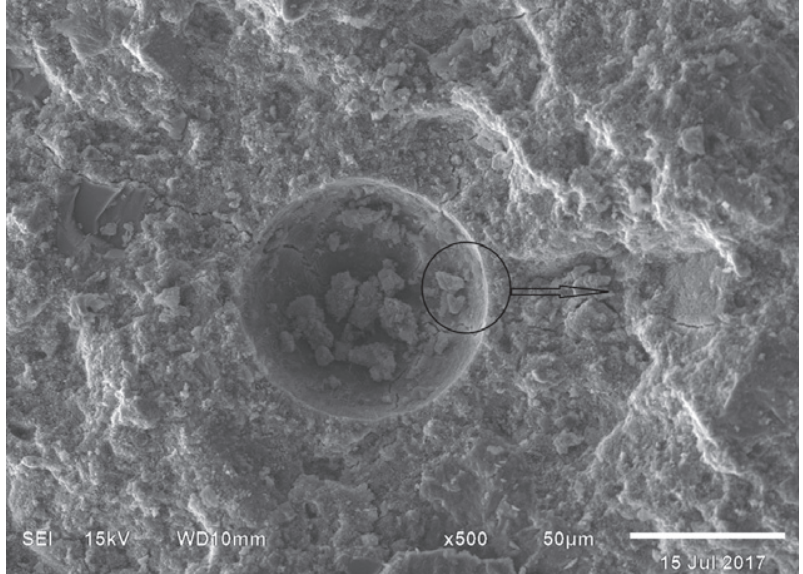

(a)

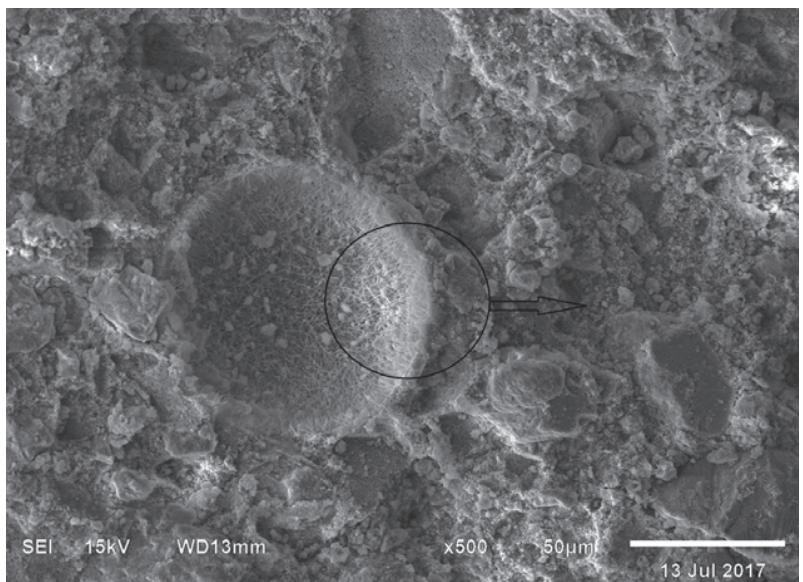

(c)

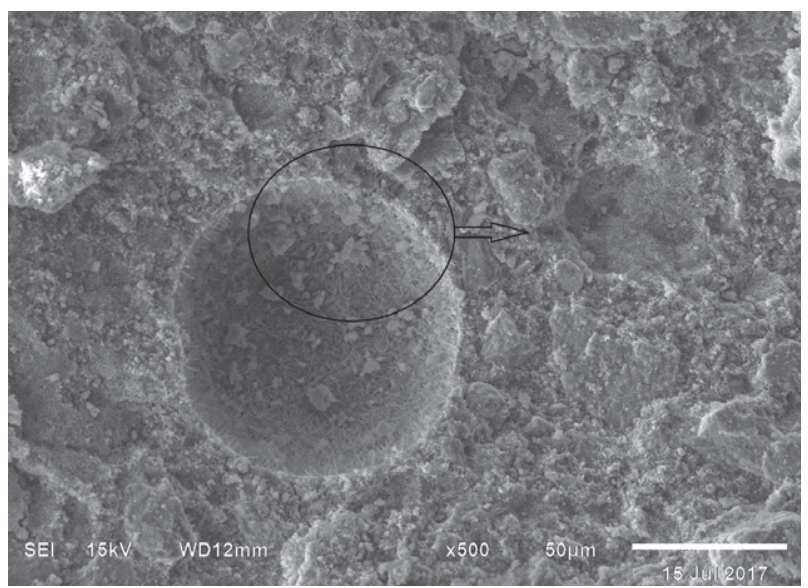

(e)

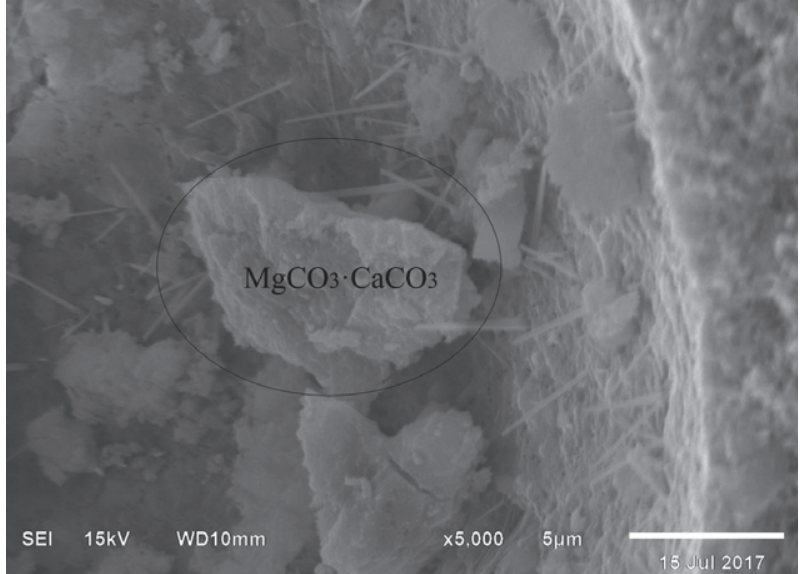

(b)

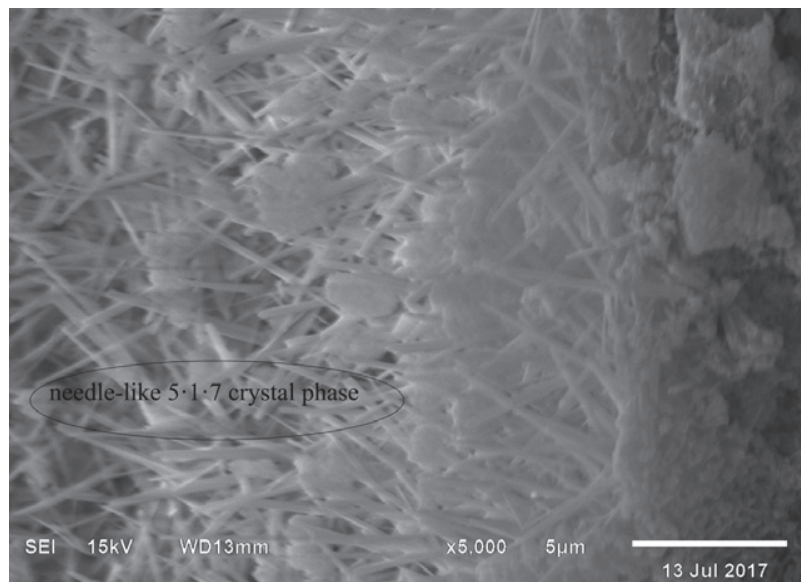

(d)

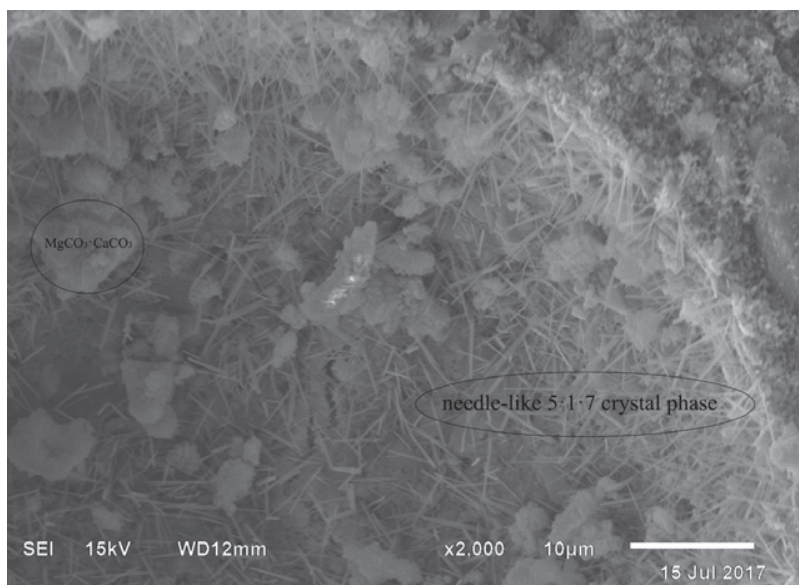

(f)

Figure 10. SEM images of MOS cement cured for $28 d$ with $\alpha$-magnesium oxide/magnesium sulfate ratio of 4 prepared by light-burned dolomite: (a), (b) T750T1·5; (c), (d) T850T0·5; (e), (f) T850T1

the calcination temperature of $850^{\circ} \mathrm{C}$, the content of $\alpha$-magnesium oxide after calcination for $1 \mathrm{~h}$ was about $18 \cdot 22 \%$, which was higher than after calcination for $0.5 \mathrm{~h}$. As shown in Figure 8 and Table 6, the dihydrate gypsum in the MOS cement is available. On the one hand, the Gibbs free energy in
Equation III is less than zero, indicating that calcium carbonate can react with magnesium sulfate spontaneously. Figure 9 shows that the compositions phase of the calcium carbonate with analytical purity dissolved in $25.0 \%$ magnesium sulfate solution ( $3 \mathrm{~d})$, could verify that there was a small amount of calcium 
carbonate dissolving in the hydration process of the MOS cement produced by light-burned dolomite, and $\mathrm{Ca}^{2+}$ combined with the solution of $\mathrm{SO}_{4}{ }^{2-}$ to produce dihydrate gypsum. On the other hand, based on Equations I and II, a small amount of free lime (see Table 5) in the light-burned dolomite reacts with water and magnesium sulfate to form dihydrate gypsum (see Figure 6). Table 6 and Figure 8 show that the content of dihydrate gypsum gradually increases as the calcination time extends. The content of dihydrate gypsum in the MOS cement of T850T1 was higher than dihydrate gypsum in the MOS cement of T850T0.5 (see Table 6). According to the mentioned results, the $\mathrm{Ca}^{2+}$ combined with $\mathrm{SO}_{4}{ }^{2-}$ to form dihydrate gypsum (Equations I-III), which resulted in reducing the $\mathrm{SO}_{4}{ }^{2-}$ in the hydration process of cement. Thereby, the $5 \cdot 1 \cdot 7$ phase content reduced, which can be shown in Table 6 and Figures 10(c)-10(f). At the same time, based on the results of the SEM, as shown in Figure 10(f), the MOS cement of T850T1 contained microcracks. The authors propose that excessive dihydrate gypsum leads to the appearance of microcracks in the MOS cement, which is regarded as the main reason that the later-age compressive strength of T850T1 is lower than that of T850T0.5. In addition, the content of $\alpha$ magnesium oxide with calcination times of 1 and $2 \mathrm{~h}$ at $800^{\circ} \mathrm{C}$ were $18.44 \%$ and $18.43 \%$, respectively. The values of compressive strength were $65.9 \mathrm{MPa}$ and $50.8 \mathrm{MPa}$, accordingly. As presented in Table 6 , the value of dihydrate gypsum in the MOS cement at calcination temperature of $800^{\circ} \mathrm{C}$ for $2 \mathrm{~h}$ was $5.89 \%$. In comparison with the mentioned value, the rate of dihydrate gypsum in the MOS cement with the same calcination temperature for $1 \mathrm{~h}$ was much lower (around 2.34\%). This is taken as the main reason for the existence of a trivial difference between the values of $\alpha$-magnesium oxide in the samples with the calcination times of 1 and $2 \mathrm{~h}$ at $800^{\circ} \mathrm{C}$; although there is a significant difference between the compressive strengths of the MOS cement with the calcination times of 1 and $2 \mathrm{~h}$ at the calcination temperature of $800^{\circ} \mathrm{C}$.

Consequently, the authors found that, as shown in Figure 7, the MOS cement produced by light-burned dolomite with a calcination time of $0.5 \mathrm{~h}$ at a calcination temperature of $850^{\circ} \mathrm{C}$ presented the best mechanical properties. The reason for this was that magnesite decomposed more completely in these conditions than with a shorter calcination time or at a lower calcination temperature. However, with the relatively shorter calcination time, there is a smaller crystal size and more active sites for reacting with $\mathrm{OH}^{-}, \mathrm{SO}_{4}{ }^{2+}$ and water in magnesium sulfate solution, leading to higher early compressive strength and faster hardening in comparison with longer calcination time. Furthermore, the relatively lower free lime content and less dihydrate gypsum are taken into account as important factors as well.

$$
\begin{gathered}
\mathrm{MgSO}_{4}+\mathrm{CaCO}_{3}+2 \mathrm{H}_{2} \mathrm{O} \rightarrow \mathrm{MgCO}_{3}+\mathrm{CaSO}_{4} \cdot 2 \mathrm{H}_{2} \mathrm{O} \\
\Delta G=-35 \cdot 6 \mathrm{~kJ} / \mathrm{mol}
\end{gathered}
$$

where $\Delta \mathrm{G}$ represent gibbs free energy.
Effects of $\alpha$-magnesium oxide/magnesium sulfate on mechanical properties of the MOS cement

Figure 11 shows the compressive strength of the MOS cement produced by light-burned dolomite with molar ratios of $\alpha$-magnesium oxide/magnesium sulfate equal to 3,4 and 5 and calcination time of $0.5 \mathrm{~h}$ at $850^{\circ} \mathrm{C}$ for different curing times (M3 indicates that the molar ratio of $\alpha$-magnesium oxide/ magnesium sulfate for the MOS cement with the calcination time of $0.5 \mathrm{~h}$ at $850^{\circ} \mathrm{C}$ was equal to 3 ). Based on the results provided, it can be clearly observed that the early compressive strength gradually rose with the increase of the $\alpha$-magnesium oxide/magnesium sulfate ratio. To justify this, when the molar

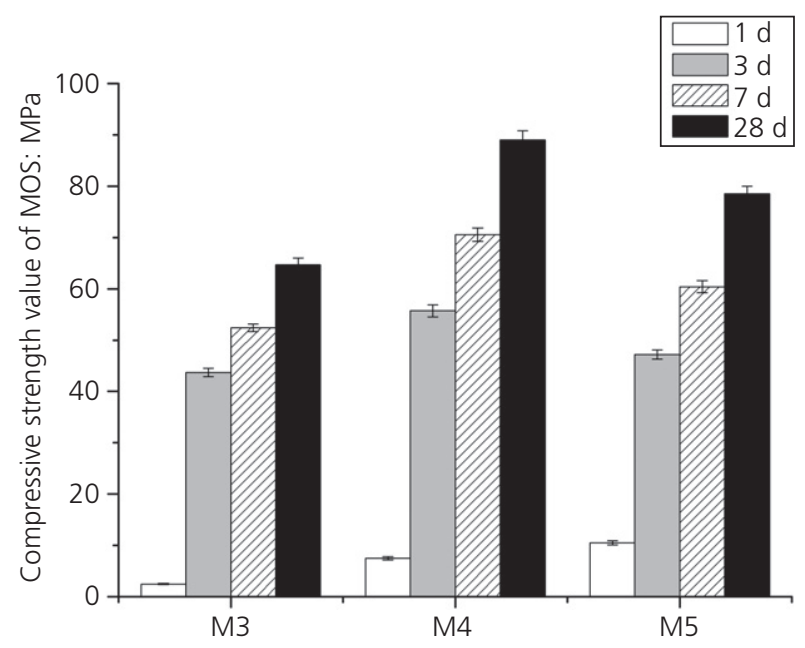

Figure 11. Compressive strength of MOS cements M3, M4 and M5 prepared by light-burned dolomite ores calcinated for $0.5 \mathrm{~h}$ at $850^{\circ} \mathrm{C}$ with different curing times

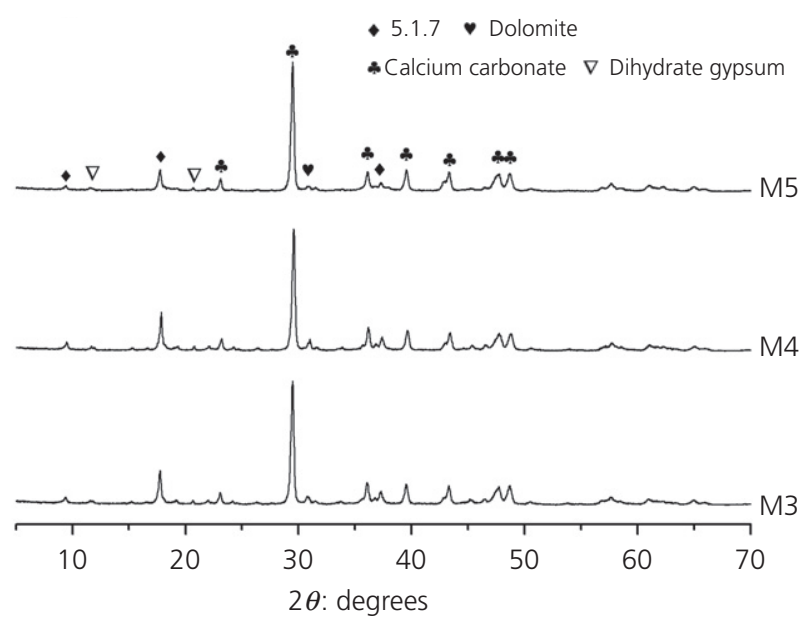

Figure 12. XRD diffractogram of MOS cements M3, M4 and M5 prepared by dolomite ores calcinated for $0.5 \mathrm{~h}$ at $850^{\circ} \mathrm{C}$ after cured for $28 \mathrm{~d}$ 
Advances in Cement Research

Volume 30 Issue 10
Study of using light-burned dolomite ores

as raw material to produce magnesium

oxysulfate cement

Chen, Wu, Yu et al.

Table 7. Phase composition of MOS cement of M3, M4, M5 cured for $28 \mathrm{~d}$ (by mass \%)

\begin{tabular}{|c|c|c|c|c|c|}
\hline $\begin{array}{l}\text { MOS } \\
\text { cement }\end{array}$ & $\begin{array}{l}\text { Calcium-magnesium carbonate } \\
\qquad\left(\mathrm{CaCO}_{3} \cdot \mathrm{MgCO}_{3}\right)\end{array}$ & $\begin{array}{l}\text { Calcium carbonate } \\
\left(\mathrm{CaCO}_{3}\right)\end{array}$ & $\begin{array}{l}\text { Magnesium oxide } \\
\text { (MgO) }\end{array}$ & $5 \cdot 1 \cdot 7$ & $\begin{array}{l}\text { Dihydrate gypsum } \\
\left(\mathrm{CaSO}_{4} \cdot 2 \mathrm{H}_{2} \mathrm{O}\right)\end{array}$ \\
\hline M3 & 1.86 & $55 \cdot 18$ & $2 \cdot 21$ & $37 \cdot 31$ & 1.43 \\
\hline M4 & 1.71 & $53 \cdot 14$ & $3 \cdot 51$ & $38 \cdot 18$ & 1.47 \\
\hline M5 & 1.08 & $58 \cdot 79$ & $5 \cdot 42$ & 31.09 & 1.62 \\
\hline
\end{tabular}

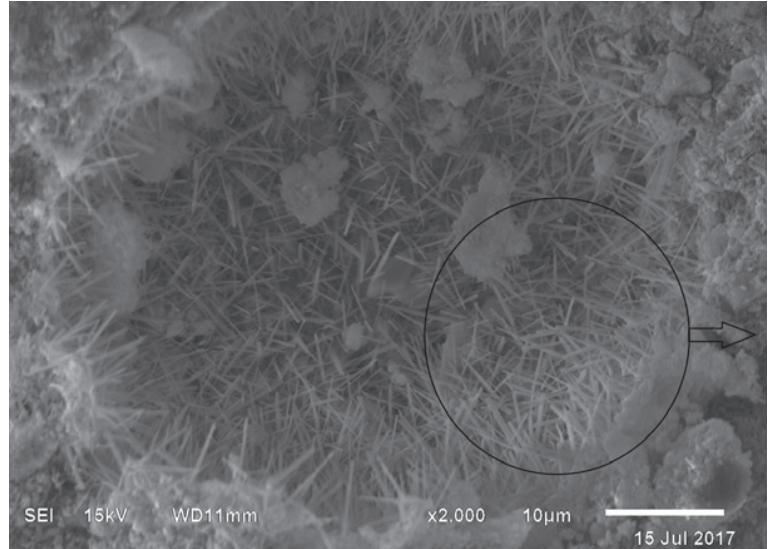

(a)

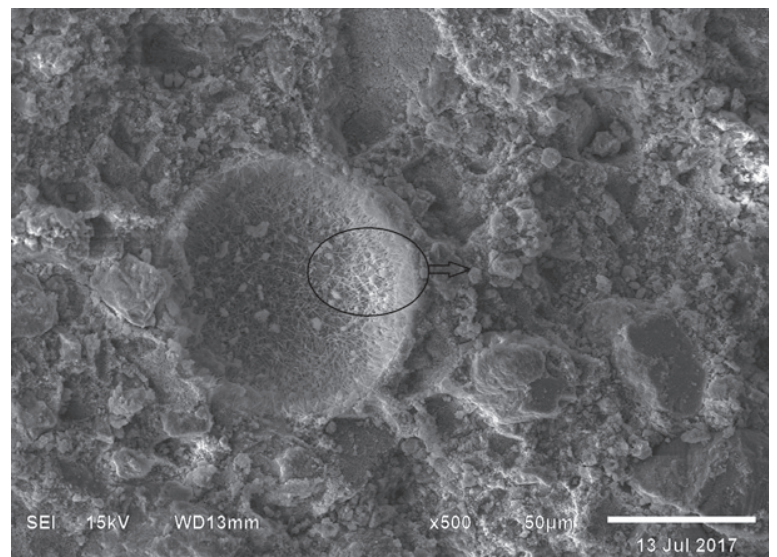

(c)

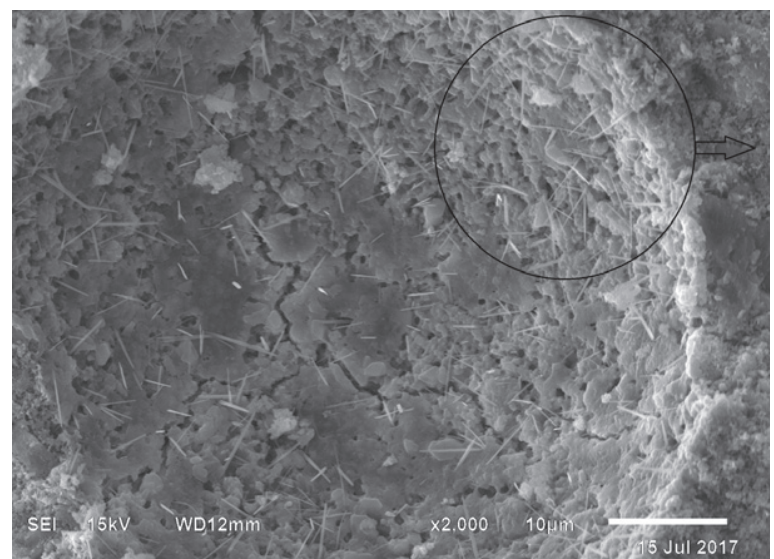

(e)

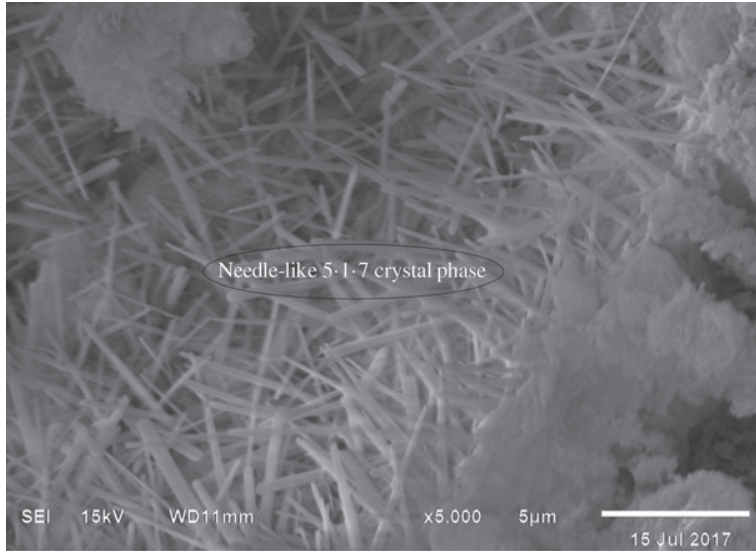

(b)

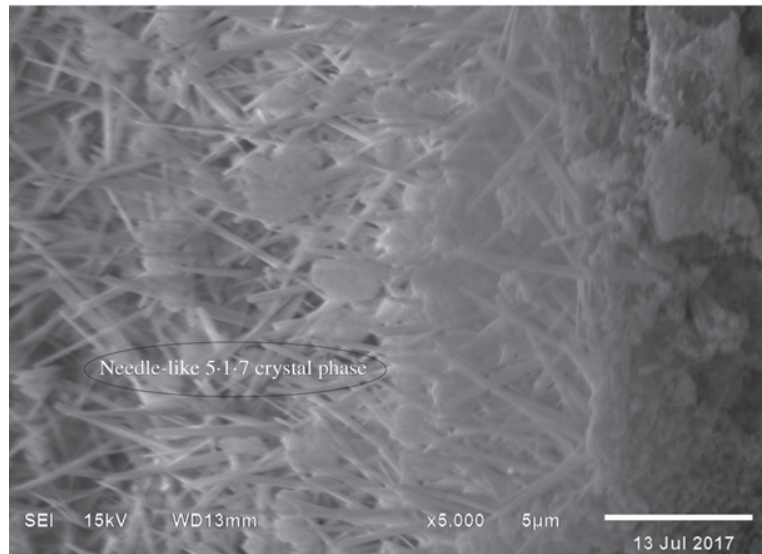

(d)

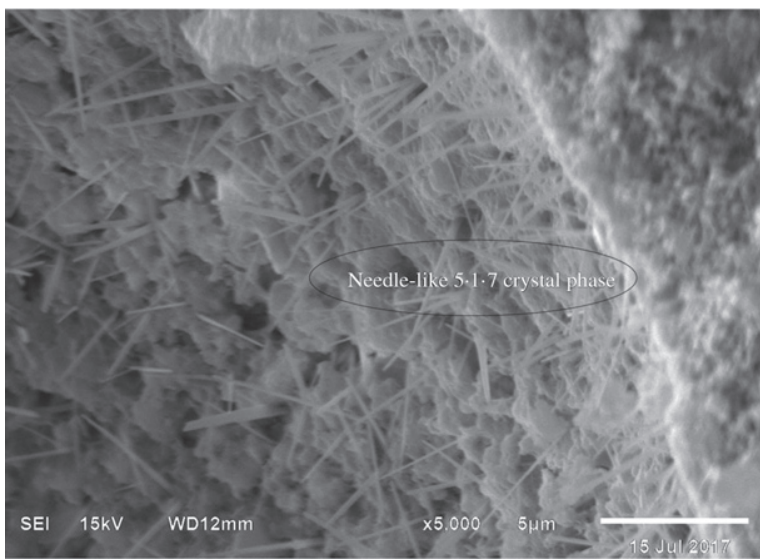

(f)

Figure 13. SEM images of MOS cements: (a), (b) M3; (c), (d) M4; (e), (f) M5 prepared by dolomite ores calcinated for $0.5 \mathrm{~h}$ at $850^{\circ} \mathrm{C}$ after curing for $28 \mathrm{~d}$ 
ratio increases, the $w / c$ gradually reduces and the setting time of the MOS cement diminishes as well (see Table 4). Hence, the early compressive strength of the MOS cement is gradually enhanced. However, the MOS cement with $\alpha$-magnesium oxide/magnesium sulfate ratio equal to 4 showed the highest later-age compressive strength, as shown in Figure 11. As illustrated in Figure 12 and Table 7 , the $5 \cdot 1 \cdot 7$ phase was at its highest content for M4. It is obvious that M3 included less $\alpha$-magnesium oxide and more magnesium sulfate and water, which resulted in an insufficient amount of magnesium oxide to produce hydration products (see Table 7). Additionally, the MOS cement of M5 consisted of more magnesium oxide and water and less magnesium sulfate, which led to less hydration products, as shown in Figure 10. Moreover, the needle-like $5 \cdot 1.7$ phase of M5 is not any denser than M3 and M4 (see Figure 13). Therefore, the compressive strength of the MOS cement of M4 represented the best mechanical strength.

Based on the analysis results, in this study, the best calcination temperature, calcination time and molar ratio of $\alpha$-magnesium oxide/magnesium sulfate of the MOS cement produced by light-burned dolomite ores were $850^{\circ} \mathrm{C}, 0.5 \mathrm{~h}$ and 4 , respectively. As shown in Figure 14, the MOS cement produced by light-burned dolomite ores without CA may contain cracks, which was similar to the MOS cement produced by LBM without CA, based on the reports by Wu et al. (2015, 2017). The calcium carbonate in the MOS cement not only acts as a filler (Zhao, 2010), but also reacts with magnesium sulfate to produce dihydrate gypsum (Equation III), which is harmful for the stability of MOS cement.

\section{Conclusions}

This study uses dolomite as a raw material to produce MOS cement with different calcination processes, and analyses the setting time, mechanical strength and the hydration-heat release rate of the MOS cement. According to the results, the following conclusions can be drawn.

(a) The main strength phase of MOS cement prepared by light-burned dolomite is the needle-like $5 \mathrm{Mg}(\mathrm{OH})_{2} \cdot \mathrm{MgSO}_{4} \cdot 7 \mathrm{H}_{2} \mathrm{O}$ crystal phase.

(b) The best calcination temperature, calcination time and molar ratio of $\alpha$-magnesium oxide/magnesium sulfate of MOS cement produced by light-burned dolomite in this study were $850^{\circ} \mathrm{C}, 0.5 \mathrm{~h}$, and 4 , respectively.

(c) It is feasible to use dolomite to replace magnesite for producing MOS cement.

To obtain better properties of MOS cement produced by lightburned dolomite, more studies should be carried out to solve the problems of long setting time, the negative effects of free lime and dihydrate gypsum in the MOS cement and so on. Eventually, further studies should be encouraged to improve the different physical features of MOS cement, which could prove significant in the popularisation of the MOS cement.

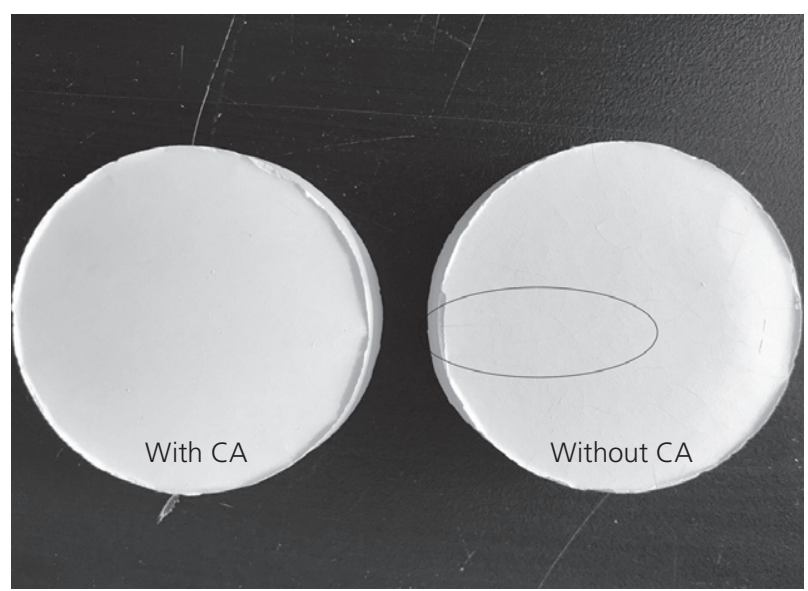

(a)

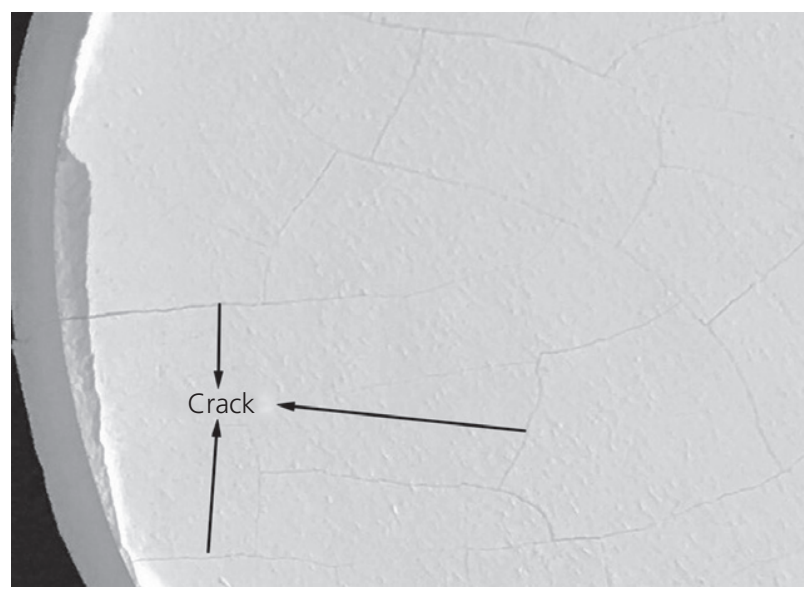

(b)

Figure 14. MOS cement prepared by light-burned dolomite at calcination temperature of $850^{\circ} \mathrm{C}$ for $0.5 \mathrm{~h}$ with molar ratio of $\alpha$-magnesium oxide/magnesium sulfate of 4 : (a) MOS cement with CA on the left-hand side, MOS cement without CA on the right-hand side; (b) partial magnification of MOS cement without CA

\section{Acknowledgements}

This study was supported by the National Natural Science Foundations of China (grant no. 51662035 and no. U1407104) and Natural Science Foundations of Qinghai Province (grants no. 2015-ZJ-937Q).

\section{REFERENCES}

Altiner M and Yildirim M (2016) Production of magnesium chloride $\left(\mathrm{MgCl}_{2}\right)$ from Aydıncık/İçel dolomites. Çukurova Üniversitesi Fen ve Mühendislik Bilimleri Dergisi 34(3): 106-113 (in Turkish).

Altiner M and Yildirim M (2017a) Study of using dolomite as starting material resource to produce magnesium oxychloride cement. Journal of Advanced Concrete Technology 15(6): 269-277.

Altiner M and Yildirim M (2017b) Preparation of periclase (MgO) nanoparticles from dolomite by pyrohydrolysis-calcination processes. Asia-Pacific Journal of Chemical Engineering 12(6):842-857. 
BSI (2005) BS EN 196-1: Methods of testing cement - part 1: determination of strength. BSI, London, UK.

Chernykh TN, Nosov AV and Kramar LY (2015) Dolomite magnesium oxychloride cement properties control method during its production. Materials Science and Engineering 71(1): 012045.

Demediuk T and Cole WF (1957) A study of magnesium oxysulphates. Australian Journal of Chemistry 10(3): 287-294.

Dong JM, Yu HF and Zhang LM (2010) Study on experimental conditions of hydration methods of determining $\alpha-\mathrm{MgO}$ content. Journal of Salt Lake Research 18(1): 38-41 (in Chinese).

Dong R, Wang MY, Zhang QY et al. (2011) Measurement for the f-CaO in dolomite half roasting product. Journal of Salt Lake Research 19(2): 25-28 (in Chinese).

Haper FC (2013) Effects of calcinations temperature on properties of $\mathrm{MgOs}$ for use in magnesium oxychloride cement. Journal of Central South University 20(12): 3729-3735 (in Chinese).

Huang HP, Yu HF, Zhang $N$ et al. (2016) Ingredients regularity and fundamental characteristics of basic magnesium sulfate cement. Bulletin of the Chinese Ceramic Society 35(8): 2561-2567 (in Chinese).

ISO (International Organization for Standardisation) (1989) ISO 679: Methods of testing cements - determination of strength. ISO, Geneva, Switzerland.

Jeffery JT (2007) A new approach to modeling the nucleation and growth kinetics of tricalcium silicate hydration. Journal of the American Ceramic Society 90(10): 3282-3288.

Kahle K (1972) Mechanism formation of magnesium-sulfate cements. Silikatech-nik 23(5): 148-151.

Kishimoto T and Yamamoto S (2009) Modified Magnesium Oxysulfate Fibrous Particles and Polyolefin Composition Containing the Same [P]. US Patent US20090292047-A1, Nov.

Li $Z$ and Chau CK (2008) Reactivity and function of $\mathrm{MgO}$ in Soresl cement. Journal of Materials in Civil Engineering 20(3): 239-244.

Ren S, Wang XJ, Wu YN and Zong J (2010) Influences of calcining and slaking processes on activity of dolomite. Inorganic Chemicals Industry 42(2): 34-35 (in Chinese).
Rietveld HM (1967) Line profiles of neutron powder-diffraction peaks for structure refinement. Acta Crystallographica 22(1): 151-152.

Runčevski T, Wu CY, Yu HF, Yang B and Dinnebier RE (2013) Structural characterization of a new magnesium oxysulfate hydrate cement phase and its surface reactions with atmospheric carbon dioxide. Journal of the American Ceramic Society 96(11): 3609-3616.

SAC (Standardisation Administration of China) (2005) GB/T 14799 : Geotextiles and geotextile-related products - determination of the effective opening size - dry sieving method. SAC, Beijing, China.

SAC (2007) GB 175: Common Portland cement. SAC, Beijing, China.

SAC (2008) GB/T 12959: Test methods for heat of hydration of cement. SAC, Beijing, China.

SAC (2011) GB/T 1346: Test methods for water requirement of normal consistency, setting time, and soundness of the portland cement. SAC, Beijing, China.

Shi HS (1995) Effect mechanism of f-CaO in cement hydration hardening process. Cement 9: 6-9, http://dx.doi.org/10.13739/ j.cnki.cn11-1899/tq.1995.09.002 (in Chinese).

Tan YS, Yu HF, Li Y et al. (2014) Magnesium potassium phosphate cement prepared by the byproduct of magnesium oxide after producing $\mathrm{Li}_{2} \mathrm{CO}_{3}$ from salt lakes. Ceramics International $\mathbf{4 0}(8)$ : 13543-13551.

Urwong L and Sorrell CA (1980) Phase relations in magnesium oxysulfate cements. Journal of the American Ceramic Society 63(9-10): 523-526.

Wu CY, Yu HF, Zhang HF, Dong JM and Zheng LN (2014) Effects of material ratio, fly ash, and citric acid on magnesium oxysulfate cement. ACI Materials Journal 111(3): 291-297.

Wu CY, Yu HF, Zhang HF et al. (2015) Effects of phosphoric acid and phosphates on magnesium oxysulfate cement. Materials \& Structures 48(4): 907-917.

Wu CY, Chen WH, Zhang HF et al. (2017) The hydration mechanism and performance of modified magnesium oxysulfate cement by tartaric acid. Construction and Building Materials 144: 516-524, http://dx.doi.org/10.1016/j.conbuildmat.2017.03.222.

Zhao F (2010) Research on dolomite to Soresl cement production. The World of Building Materials 31(2): 9-12 (in Chinese).

\section{How can you contribute?}

To discuss this paper, please submit up to 500 words to the editor at journals@ice.org.uk. Your contribution will be forwarded to the author(s) for a reply and, if considered appropriate by the editorial board, it will be published as a discussion in a future issue of the journal. 